\title{
Laboratory measurements of trace gas emissions from biomass burning of fuel types from the southeastern and southwestern United States
}

\author{
I. R. Burling ${ }^{1}$, R. J. Yokelson ${ }^{1}$, D. W. T. Griffith ${ }^{2}$, T. J. Johnson ${ }^{3}$, P. Veres ${ }^{4,5}$, J. M. Roberts ${ }^{5}$, C. Warneke ${ }^{5,6}$, \\ S. P. Urbanski ${ }^{7}$, J. Reardon ${ }^{7}$, D. R. Weise ${ }^{8}$, W. M. Hao ${ }^{7}$, and J. de Gouw ${ }^{5,6}$ \\ ${ }^{1}$ University of Montana, Department of Chemistry, Missoula, MT 59812, USA \\ ${ }^{2}$ University of Wollongong, Department of Chemistry, Wollongong, New South Wales 2522, Australia \\ ${ }^{3}$ Pacific Northwest National Laboratories, Richland WA 99354, USA \\ ${ }^{4}$ Department of Chemistry and Biochemistry, University of Colorado, Boulder, CO 80309, USA \\ ${ }^{5}$ Chemical Sciences Division, Earth System Research Laboratory, National Oceanic and Atmospheric Administration, \\ Boulder, CO 80305, USA \\ ${ }^{6}$ Cooperative Institute for Research in Environmental Sciences, University of Colorado, Boulder, CO 80309, USA \\ ${ }^{7}$ USDA Forest Service, Rocky Mountain Research Station, Fire Sciences Laboratory, Missoula, MT 59808, USA \\ ${ }^{8}$ USDA Forest Service, Pacific Southwest Research Station, Forest Fire Laboratory, Riverside, CA, USA
}

Received: 7 June 2010 - Published in Atmos. Chem. Phys. Discuss.: 1 July 2010

Revised: 9 November 2010 - Accepted: 18 November 2010 - Published: 25 November 2010

\begin{abstract}
Vegetation commonly managed by prescribed burning was collected from five southeastern and southwestern US military bases and burned under controlled conditions at the US Forest Service Fire Sciences Laboratory in Missoula, Montana. The smoke emissions were measured with a large suite of state-of-the-art instrumentation including an open-path Fourier transform infrared (OP-FTIR) spectrometer for measurement of gas-phase species. The OPFTIR detected and quantified 19 gas-phase species in these fires: $\mathrm{CO}_{2}, \mathrm{CO}, \mathrm{CH}_{4}, \mathrm{C}_{2} \mathrm{H}_{2}, \mathrm{C}_{2} \mathrm{H}_{4}, \mathrm{C}_{3} \mathrm{H}_{6}, \mathrm{HCHO}, \mathrm{HCOOH}$, $\mathrm{CH}_{3} \mathrm{OH}, \mathrm{CH}_{3} \mathrm{COOH}$, furan, $\mathrm{H}_{2} \mathrm{O}, \mathrm{NO}, \mathrm{NO}_{2}, \mathrm{HONO}, \mathrm{NH}_{3}$, $\mathrm{HCN}, \mathrm{HCl}$, and $\mathrm{SO}_{2}$. Emission factors for these species are presented for each vegetation type burned. Gas-phase nitrous acid (HONO), an important $\mathrm{OH}$ precursor, was detected in the smoke from all fires. The HONO emission factors ranged from 0.15 to $0.60 \mathrm{~g} \mathrm{~kg}^{-1}$ and were higher for the southeastern fuels. The fire-integrated molar emission ratios of $\mathrm{HONO}$ (relative to $\mathrm{NO}_{\mathrm{x}}$ ) ranged from approximately 0.03 to 0.20 , with higher values also observed for the southeastern fuels. The majority of non-methane organic compound
\end{abstract}

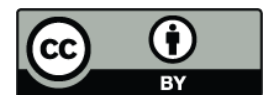

Correspondence to: R. J. Yokelson (bob.yokelson@umontana.edu)
(NMOC) emissions detected by OP-FTIR were oxygenated volatile organic compounds (OVOCs) with the total identified OVOC emissions constituting $61 \pm 12 \%$ of the total measured NMOC on a molar basis. These OVOC may undergo photolysis or further oxidation contributing to ozone formation. Elevated amounts of gas-phase $\mathrm{HCl}$ and $\mathrm{SO}_{2}$ were also detected during flaming combustion, with the amounts varying greatly depending on location and vegetation type. The fuels with the highest $\mathrm{HCl}$ emission factors were all located in the coastal regions, although $\mathrm{HCl}$ was also observed from fuels farther inland. Emission factors for $\mathrm{HCl}$ were generally higher for the southwestern fuels, particularly those found in the chaparral biome in the coastal regions of California.

\section{Introduction}

Biomass burning is a significant global source of trace gases and particles in the atmosphere and has strong impacts on both the chemical composition and radiative balance of the atmosphere (Crutzen and Andreae, 1990). In the United States, from 1998-2008 the annual average number of reported wild and prescribed fires was $\sim 80000$ and 14000 ,

Published by Copernicus Publications on behalf of the European Geosciences Union. 
respectively. The average area burned was $\sim 2.6$ Mha and 0.9 Mha annually for wild and prescribed fires, respectively (US National Interagency Fire Center, http://www.nifc.gov/ fire_info/fire_stats.htm). Prescribed burning of biomass is a commonly used land management tool, with benefits including the reduction of wildfire hazards, improvement of wildlife habitats, and improved access (Biswell, 1999; Wade and Lunsford, 1989). Many fire-adapted ecosystems depend on the regular occurrence of fire for survival.

For biomass burning, the amount of emissions of any compound is affected by many factors, including the combustion processes of the fire (e.g. flaming or smoldering) and also the fuel chemistry, moisture, and geometry (Andreae and Merlet, 2001). The gas-phase emissions from biomass burning are dominated by water vapor $\left(\mathrm{H}_{2} \mathrm{O}\right)$ and carbon dioxide $\left(\mathrm{CO}_{2}\right)$, but also include significant amounts of many other compounds such as carbon monoxide (CO), nitric oxide (NO), nitrogen dioxide $\left(\mathrm{NO}_{2}\right)$, methane $\left(\mathrm{CH}_{4}\right)$, ammonia $\left(\mathrm{NH}_{3}\right)$, and a multitude of non-methane organic compounds (NMOC) of which oxygenated volatile organic compounds (OVOC) comprise a large fraction (Christian et al., 2003; Christian et al., 2004). These NMOC may contribute to photochemical ozone $\left(\mathrm{O}_{3}\right)$ production and secondary organic aerosol (SOA) formation. Gas-phase nitrous acid (HONO) has been observed in biomass burning plumes both in the laboratory (Keene et al., 2006; Roberts et al., 2010) and in the field (Yokelson et al., 2007a; Yokelson et al., 2009). HONO is an important photolytic source of hydroxyl $(\mathrm{OH})$ radicals; however, the mechanisms of HONO formation are not fully understood (Kleffmann, 2007; Stutz et al., 2010). Knowledge of the HONO formation mechanisms is important for modeling of the chemical processes as a plume ages. HONO has also been observed as a direct emission from other combustion processes (Finlayson-Pitts and Pitts (2000) and references therein).

A useful technique for the measurement of gas-phase emissions from biomass burning is open-path Fourier transform infrared (OP-FTIR) spectroscopy. An advantage of OPFTIR is that it is able to quantify most reactive and stable compounds at mixing ratios at or above a few ppbv. In addition, the open-path nature of the measurement produces no sampling or storage artifacts, and all compounds are measured simultaneously and path-integrated through the same air parcel. The unique spectral features of the species measured means the technique is resistant to interference and provides unambiguous compound identification. Also, OPFTIR has high temporal resolution for monitoring of dynamic processes related to emissions of biomass fires (Yokelson et al., 1996).

While field measurements are essential to characterize smoke from real fires, laboratory studies offer many advantages (Yokelson et al., 2008). More extensive instrumentation can be utilized in laboratory fire studies, and since smoke concentrations tend to be higher, more species can be quantified. Also, in a laboratory experiment, all the smoke dur- ing the entire course of a fire can be sampled, so that emission factors can be determined with high accuracy, whereas field measurements are typically limited to sampling a much smaller fraction of the total smoke. Characterization and measurement of the composition of fuels and the conditions under which they are burned is easier in the laboratory.

In 2008, the Strategic Environmental Research and Development Program (SERDP) initiated three projects to characterize smoke chemistry and transport associated with prescribed burns on US Department of Defense (DoD) lands. The projects focused on prescribed burns in chaparral and Madrean oak woodlands in the southwestern United States and pine forests in the southeastern US. Detailed measurements of gaseous and particulate emissions were made in laboratory and field experiments. Post-emission transport and the chemical evolution of smoke were measured and will be simulated with photochemical models (Alvarado and Prinn, 2009; Byun and Schere, 2006). In the laboratory component, fuels representative of vegetation commonly managed by prescribed burning on several southeastern and southwestern DoD bases were collected and burned under controlled conditions at the US Forest Service (USFS) Fire Sciences Laboratory (FSL) in Missoula, MT. The emissions from these laboratory burns were analyzed with a large suite of state-ofthe-art instrumentation. The data from these laboratory burns will be synthesized with data from field measurements (both airborne and ground-based) of prescribed burns of the same fuels on DoD bases. The objective of the present study is to present emission factors of the gas-phase species measured by OP-FTIR in the laboratory.

\section{Experimental details}

\subsection{Fire Sciences Laboratory combustion facility}

The details of the combustion facility at the FSL are shown in Fig. 1 and have been described elsewhere (Christian et al., 2003). Briefly, the combustion facility is a large chamber measuring $12.5 \mathrm{~m} \times 12.5 \mathrm{~m} \times 22 \mathrm{~m}$ high. A $1.6 \mathrm{~m}$ diameter exhaust stack with a $3.6 \mathrm{~m}$ diameter inverted funnel opening extends from $\sim 2 \mathrm{~m}$ above the floor to the top of the chamber. Outside air is conditioned for temperature and relative humidity and slightly pressurizes the combustion chamber. This air is vented through the stack and entrains the emissions from fires burning directly beneath the funnel. A large sampling platform supporting the OP-FTIR and the majority of the instrumentation surrounds the stack $17 \mathrm{~m}$ above the fuel bed. Temperature and mixing ratios are constant across the width of the stack at the height of the sampling platform (Christian et al., 2003; Christian et al., 2004), providing a well-mixed sample. The fuel bed consisted of an aluminum frame with a wire grid. 


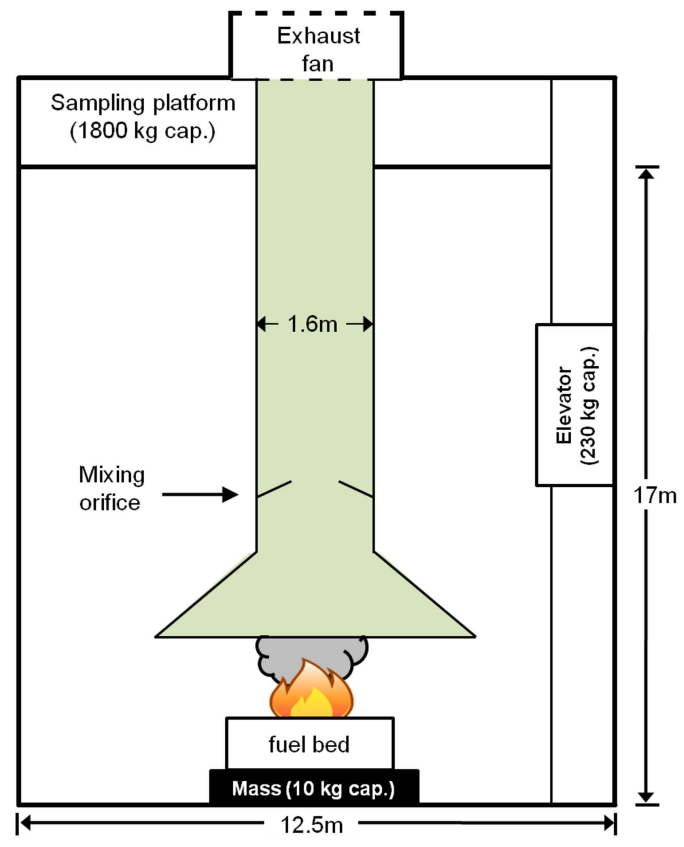

Fig. 1. Schematic of combustion chamber at Missoula FSL.

\subsection{Fuel descriptions and laboratory setup}

Samples representing fuels commonly managed by prescribed burning were collected in January 2009 from Camp Lejeune, North Carolina (NC) and Fort Benning, Georgia (GA) in the southeastern US, and Fort Hunter-Liggett, California (CA), Vandenberg Air Force Base (CA), and Fort Huachuca, Arizona (AZ) in the southwestern US. The species composition and other details of the samples burned in this study are listed in Table 1 . We briefly describe the fuels here starting with the southeast. Pocosin (fuel code in tables and figures is "poc") is a dense shrub/pine complex that is extremely flammable during drought. The pocosin site was a mix of mature fetterbush (Lyonia lucida) and gallberry (Ilex glabra). The understory hardwood ("uh") samples were mostly understory red (Persea borbonia) and loblolly bays (Gordonia lasianthus) and some red maple (Acer rubrum). Some of the samples from Camp Lejeune represented different stages after mechanical fuel treatment and/or burning at that location. The chipped understory hardwood ("cuh") samples were mostly larger diameter red maple, red bay and loblolly bay that had been recently mechanically masticated. Our samples were of the smaller diameter pieces (less than $\sim 5 \mathrm{~cm}$ ) of various lengths (up to $\sim 30 \mathrm{~cm}$ ) as these are the components that are most likely to burn in a prescribed fire. The "one-year rough" ("1yr") and "two-year rough" ("2yr") samples refer to understory regrowth one and two years after burning and they were dominated by a mix of gallberry, fetterbush and graminoids (grasses). The Fort Benning samples ("lit") were litter from various aged southern pine stands.
The southwestern samples from California were of six types of the dense, evergreen chaparral shrub complex common in much of California. The various types are shown in Table 1 along with their fuel codes. Chaparral covers roughly 2.5 million hectares and is known for its intense crown fires, which can impact urban areas (Keeley and Davis, 2007). The Fort Huachuca samples from Arizona were from plant communities of the Sonoran Desert and the Madrean archipelago (sky islands) and consisted of masticated mesquite (Prosopis velutina) and desert broom (Baccharis sarothroides) ("mes"), oak savanna (Emory oak (Quercus emoryi) and Lehmann lovegrass, (Eragrostis lehmanniana) "oas"), and oak woodland (Emory oak and pointleaf manzanita (Arctostaphylos pungens), "oaw"). We also burned some additional samples including a duff sample ("duf") from a black spruce (Picea mariana) forest in Alaska (AK), as well as Englemann spruce ("spr," Picea engelmannii) branches, and ponderosa pine (Pinus ponderosa) needles ("ppn") from Montana (MT).

After collection, the fuel samples were sent to the FSL and stored for 3 to 4 weeks before burning in the laboratory. The fuel samples were re-assembled in the combustion chamber based on site photographs and fuel loading measurements. With the exception of the pine litter, masticated mesquite, and chipped understory hardwood fuel types, these fuels tend to have a vertical orientation in the natural setting where wind and slope often improve heat transfer and fire propagation. We initially attempted to burn the southwestern fuels in this orientation, but had limited success so the remaining southwestern fuels were oriented horizontally while maintaining a realistic mass per area so that the fire carried better. Nearly all of the fires were ignited with a propane torch. Data points corresponding to ignition were omitted from the analysis. All the burns were filmed to enable subsequent re-examination of the fire behavior. The carbon and nitrogen content of the fuels were measured by the University of Idaho, Analytical Sciences Laboratory and are shown in Table 1.

\subsection{Open-path Fourier transform infrared spectrometer details}

The open-path Fourier transform infrared (OP-FTIR) instrument consisted of a Bruker Matrix-M IR Cube spectrometer ${ }^{1}$ and a thermally stable open-path White cell. The $58.0 \mathrm{~m}$ path length White cell was positioned on the sampling platform approximately $17 \mathrm{~m}$ above the fuel bed so that the open path spanned the full diameter of the stack directly in the rising emissions stream. We performed several tests to determine the best spectrometer sampling options, including measurement duty cycle, sample frequency, and spectral resolution. Ultimately, we acquired spectra every $1.5 \mathrm{~s}$ (four co-added

\footnotetext{
${ }^{1}$ Tradenames are presented for informational purposes only and do not constitute endorsement by the US Department of Agriculture.
} 
Table 1. Summary of vegetation burned and fuel elemental analysis (see Sect. 2.2 for fuel descriptions).

\begin{tabular}{|c|c|c|c|c|c|c|}
\hline Fuel Type & Species Names & Fuel Code & Location $^{1}$ & \# Burns ${ }^{2}$ & $\begin{array}{l}\text { C-content } \\
(\%)\end{array}$ & $\begin{array}{l}\text { N-content } \\
(\%)\end{array}$ \\
\hline \multicolumn{7}{|l|}{ SW Fuels } \\
\hline ceanothus & Ceanothus leucodermis & cea & FHL CA & $6(5)$ & 51 & 1.1 \\
\hline chamise/scrub oak & Adenostoma fasciculatum, Quercus berberidifolia & chs & FHL CA & $6(5)$ & 53 & 0.82 \\
\hline California sagebrush & Artemisia californica, Ericameria ericoides & cas & VAFB CA & $6(6)$ & 50 & 1.2 \\
\hline coastal sage scrub & Salvia mellifera, Ericameria ericoides, Artemisia californica & $\cos$ & VAFB CA & $5(3)$ & 50 & 1.04 \\
\hline maritime chaparral & $\begin{array}{l}\text { Ceanothus impressus var. impressus, C. cuneatus var. } \\
\text { fascicularis, Salvia mellifera }\end{array}$ & mch & VAFB CA & $5(5)$ & 51 & 1.15 \\
\hline manzanita & Arctostaphylos rudis, Arctostaphylos purissima & $\operatorname{man}$ & VAFB CA & $6(6)$ & 53 & 0.71 \\
\hline masticated mesquite & Prosopis velutina, Baccharis sarothroides & mes & FHUA AZ & $5(5)$ & 48 & 1.3 \\
\hline oak savanna & Quercus emoryi, Eragrostis lehmanniana & oas & FHUA AZ & $5(5)$ & 49 & 1.0 \\
\hline oak woodland & Quercus emoryi, Arctostaphylos pungens & oaw & FHUA AZ & $5(4)$ & 51 & 0.86 \\
\hline \multicolumn{7}{|l|}{ SE Fuels } \\
\hline 1 year rough & Lyonia lucida and Ilex glabra & $1 \mathrm{yr}$ & CL NC & $3(3)$ & 55 & 0.72 \\
\hline 2 year rough & Lyonia lucida and Ilex glabra & $2 \mathrm{yr}$ & CL NC & $4(4)$ & 53 & 1.0 \\
\hline chipped understory hardwood & Acer rubrum, Persea borbonia, Gordonia lasianthus & cuh & CL NC & $3(3)$ & 54 & 0.44 \\
\hline understory hardwood & Acer rubrum, Persea borbonia, Gordonia lasianthus & uh & CL NC & $3(3)$ & $50^{3}$ & -3 \\
\hline pocosin & Lyonia lucida and Ilex glabra & poc & $\mathrm{CL} \mathrm{NC}$ & $3(3)$ & 54 & 0.72 \\
\hline pine litter & Pinus taeda, Pinus echinata, Pinus elliottii, Pinus palustris & lit & FB GA & $5(5)$ & 53 & 0.58 \\
\hline \multicolumn{7}{|l|}{ Other Fuels } \\
\hline Duff (black spruce forest) & Picea mariana & duf & $\mathrm{AK}$ & $1(1)$ & 42 & 1.1 \\
\hline Englemann Spruce & Picea engelmannii & spr & MT & $2(2)$ & 53 & 0.88 \\
\hline ponderosa pine needles & Pinus ponderosa & ppn & MT & $1(1)$ & 53 & 0.48 \\
\hline
\end{tabular}

${ }^{1}$ FHL - Fort Hunter Liggett; VAFB - Vandenberg Air Force Base; FHUA - Fort Huachuca; CL - Camp Lejeune; FB - Fort Benning.

2 Number in brackets is the number of burns sampled by OP-FTIR.

${ }^{3}$ The nitrogen and carbon contents of the understory hardwood sample of Camp Lejeune were not determined. A reasonable estimate of $50 \%$ was used for the carbon content of this fuel type.

interferograms in $1.5 \mathrm{~s}$, with duty cycle $>95 \%$ ) at a spectral resolution of $0.67 \mathrm{~cm}^{-1}$ beginning several minutes prior to the fire and continuously until the end of the fire. A pressure transducer and two temperature sensors were located adjacent to the optical path and their outputs were logged on the instrument computer and used for spectral analysis.

The acquired spectra were analyzed for carbon dioxide $\left(\mathrm{CO}_{2}\right)$, carbon monoxide $(\mathrm{CO})$, methane $\left(\mathrm{CH}_{4}\right)$, ethyne $\left(\mathrm{C}_{2} \mathrm{H}_{2}\right)$, ethene $\left(\mathrm{C}_{2} \mathrm{H}_{4}\right)$, propene $\left(\mathrm{C}_{3} \mathrm{H}_{6}\right)$, formaldehyde ( $\mathrm{HCHO})$, formic acid $(\mathrm{HCOOH})$, methanol $\left(\mathrm{CH}_{3} \mathrm{OH}\right)$, acetic acid $\left(\mathrm{CH}_{3} \mathrm{COOH}\right)$, furan $\left(\mathrm{C}_{4} \mathrm{H}_{4} \mathrm{O}\right)$, water $\left(\mathrm{H}_{2} \mathrm{O}\right)$, nitric oxide (NO), nitrogen dioxide $\left(\mathrm{NO}_{2}\right)$, nitrous acid (HONO), ammonia $\left(\mathrm{NH}_{3}\right)$, hydrogen cyanide $(\mathrm{HCN})$, hydrogen chloride $(\mathrm{HCl})$, and sulfur dioxide $\left(\mathrm{SO}_{2}\right)$. Mixing ratios were obtained by multi-component fits to selected sections of the mid-IR transmission spectra with a synthetic calibration nonlinear least-squares method (Griffith, 1996; Yokelson et al., 2007a) utilizing both the HITRAN (Rothman et al., 2009) spectral database and reference spectra recorded at Pacific Northwest National Laboratory (PNNL) (Sharpe et al., 2004; Johnson et al., 2006, 2010). The species above accounted for nearly all the features observed in the smoke spectra. A comparison of our experimental smoke spectra to published reference spectra confirmed that several compounds that have been detected in past smoke studies by FTIR, such as ethane, glycolaldehyde, carbonyl sulfide, isoprene, and 1butene were not present in detectable quantities.

\subsection{Additional instrumentation details}

In addition to OP-FTIR, gas-phase measurements were also performed by (1) two proton-transfer-reaction mass spectrometers (PTR-MS) for measurement of non-methane organic compounds (NMOC) (de Gouw and Warneke, 2007), (2) proton-transfer ion trap-mass spectrometry (PITMS) (Warneke et al., 2005) for NMOC, (3) negative-ion proton-transfer chemical-ionization mass spectrometry (NIPT-CIMS) (Veres et al., 2008) for detection of organic and inorganic acids, (4) gas chromatography mass spectrometry (GC-MS) for NMOC (Goldan et al., 2004), (5) canister sampling followed with analysis by gas chromatography flame ionization detection (GC-FID) (Hao et al., 1996) for low molecular weight hydrocarbons, (6) $\mathrm{LICOR} \mathrm{CO}_{2}$ analyzer, and (7) TECO CO analyzer. Due to platform space and load restrictions, one PTR-MS and the GC-MS were housed in a control room adjacent to the combustion chamber and connected to the stack by a long Teflon sampling line. Together these additional instruments provided measurements 
of approximately one hundred additional trace gases. To characterize the particle emissions, several instruments located on the platform measured size distributions, number, mass, and composition. Full descriptions and results from the other individual instruments will be published elsewhere (Hosseini et al., 2010; Roberts et al., 2010; Veres et al., 2010; Warneke et al., 2010).

\subsection{Emission ratio and emission factor calculations}

Excess mixing ratios above background (denoted as $\Delta X$ for any species " $X$ ") were calculated for each OP-FTIR measurement (every $1.5 \mathrm{~s}$ ) by subtraction of a 60 -s average mixing ratio measured prior to the ignition of the fire. Excess mixing ratios were integrated over the whole fire for emission factor and mass balance calculations. Fire-integrated molar emission ratios, $\mathrm{ER}(X / Y)$, for species $X$ relative to species $Y$ (usually $\mathrm{CO}_{2}$ or $\mathrm{CO}$ ), were calculated by:

$\operatorname{ER}(X / Y)=\frac{\sum \Delta X}{\sum \Delta Y}$

Emission ratios can be computed for any point in time during a fire (Yokelson et al., 1996), but in this paper we present only fire-integrated emission ratios.

Since the emissions from the various combustion processes (e.g. flaming and smoldering) are different, a useful quantity describing the relative amount of flaming or smoldering combustion is the modified combustion efficiency, MCE, defined as (Yokelson et al., 1996):

$\mathrm{MCE}=\frac{\Delta \mathrm{CO}_{2}}{\Delta \mathrm{CO}_{2}+\Delta \mathrm{CO}}$

Higher MCE values indicate more flaming and lower MCE more smoldering combustion. As with emission ratios, MCE can be computed for any point in time during a fire (Yokelson et al., 1996), but here we present only fire-integrated MCE for comparison to fire-integrated emissions.

Fire-integrated emission factors, $\mathrm{EF}(X)$ (grams of species $X$ emitted per kilogram dry fuel burned) were calculated by the carbon mass-balance method (Yokelson et al., 1999):

$\mathrm{EF}(X)(\mathrm{g} / \mathrm{kg})=F_{\mathrm{c}} \cdot 1000 \cdot \frac{\mathrm{MW}_{X}}{12} \cdot \frac{C_{X}}{C_{T}}$

where $F_{\mathrm{c}}$ is the carbon mass fraction of the fuel determined experimentally (Table 1 ); $\mathrm{MW}_{\mathrm{x}}$ is the molecular weight of species $X, 12$ is the atomic mass of carbon and $C_{X} / C_{T}$ is the number of moles emitted of species $X$ divided by the total number of moles of carbon emitted, given by the following:

$$
\frac{C_{X}}{C_{T}}=\frac{\frac{\Delta X}{\Delta \mathrm{CO}_{2}}}{\sum_{j=1}^{n}\left(\mathrm{NC}_{j} \cdot \frac{\Delta C_{j}}{\Delta \mathrm{CO}_{2}}\right)}
$$

where $\mathrm{NC}_{j}$ is the number of carbons in species $j$. Since the majority of the carbon mass (98-99\%) is in the compounds $\mathrm{CO}_{2}, \mathrm{CO}$, and $\mathrm{CH}_{4}$ (all of which were measured by
OP-FTIR) by considering only the carbon-containing compounds that are detected by the OP-FTIR in the mass balance approach inflates the emission factors by $\sim 1-2 \%$ (Yokelson et al., 2007a).

\section{Results and discussion}

The arrangement of the fuel on the bed significantly affected fuel consumption. At the beginning of the experiment, we arranged the chamise/scrub oak fuels vertically as found in nature, but the fire failed to spread, resulting in average consumption of $30 \%$ for this fuel type. Next, three of the ceanothus fuel beds were burned vertically with consumption ranging from $3 \%$ to $52 \%$ and three were burned horizontally with consumption ranging from $77 \%$ to $93 \%$. The fuel beds for the remaining southwestern fuel types were arranged horizontally which greatly increased fuel consumption to $90 \%$ for all other southwestern fuel types. The two replicates with the lowest fuel consumption, the vertically oriented ceanothus (3\% fuel consumption) and chamise/scrub oak (9.5\%), were not included since the smoke from the biomass of these two burns was difficult to distinguish from the ignition sources. While there may be a correlation between emission factors and fuel consumption, we do not have enough data to probe the correlation statistically. The southeast has higher annual rainfall and higher biomass production than the southwest, which can lead to denser fuel beds with more efficient heat transfer when the fuel is burned. Thus, most of our replicated southeast fuel beds burned well even in a vertical orientation.

We sampled a total of 77 fires (71 from southeastern and southwestern fuel beds) at the FSL combustion facility in February 2009. Figure 2 shows temporal profiles for the excess mixing ratios of 18 gas-phase compounds measured by OP-FTIR for a complete fire. Immediately after ignition, the fire is characterized by a rapid, large increase in $\mathrm{CO}_{2}$ corresponding to vigorous flaming, followed by a slower increase in $\mathrm{CO}$ from smoldering combustion. As is typical for these types of fires, there is often no clear distinction between flaming and smoldering but rather a mix of the two processes as the convective updraft from the heat produced by flaming can entrain emissions from smoldering combustion as the flame travels horizontally along the fuel bed (Urbanski et al., 2009; Yokelson et al., 1996). Those species measured by the OP-FTIR associated with flaming combustion include $\mathrm{CO}_{2}, \mathrm{NO}, \mathrm{NO}_{2}, \mathrm{HCl}, \mathrm{SO}_{2}$, and $\mathrm{HONO}$ while those associated with smoldering combustion include $\mathrm{CO}$, $\mathrm{CH}_{4}, \mathrm{NH}_{3}, \mathrm{C}_{3} \mathrm{H}_{6}, \mathrm{CH}_{3} \mathrm{OH}, \mathrm{CH}_{3} \mathrm{COOH}$, and $\mathrm{C}_{4} \mathrm{H}_{4} \mathrm{O}$ (furan). The species $\mathrm{C}_{2} \mathrm{H}_{2}, \mathrm{C}_{2} \mathrm{H}_{4}, \mathrm{HCOOH}$, and $\mathrm{HCHO}$ can be associated with both flaming and smoldering combustion (Lobert et al., 1991; Yokelson et al., 2008).

Fire-integrated emission factors and emission ratios to $\mathrm{CO}$ and $\mathrm{CO}_{2}$ were determined for all fires. We use mass-based $\mathrm{EF}$ and molar ER in this discussion when appropriate for 
Table 2. Emission factors ${ }^{1}\left(\mathrm{~g} \mathrm{~kg}^{-1}\right)$ of gas-phase species for southwestern fuels.

\begin{tabular}{|c|c|c|c|c|c|c|c|c|c|c|c|c|}
\hline & $\begin{array}{l}\text { FHL } \\
\text { cea }^{2}\end{array}$ & $\begin{array}{r}\text { FHL } \\
\text { chs }\end{array}$ & $\begin{array}{r}\mathrm{VAFB} \\
\text { cas }\end{array}$ & $\begin{array}{r}\mathrm{VAFB} \\
\cos \end{array}$ & $\begin{array}{r}\text { VAFB } \\
\text { man }\end{array}$ & $\begin{array}{r}\text { VAFB } \\
\text { mch }\end{array}$ & $\begin{array}{r}\text { Chaparral } \\
\text { average }\end{array}$ & $\begin{array}{r}\text { Chaparral } \\
\text { (Radke et al., 1991) }\end{array}$ & $\begin{array}{r}\text { FHUA } \\
\text { mes }\end{array}$ & $\begin{array}{r}\text { FHUA } \\
\text { oas }\end{array}$ & $\begin{array}{r}\text { FHUA } \\
\text { oaw }\end{array}$ & $\begin{array}{r}\text { FHUA } \\
\text { average }\end{array}$ \\
\hline MCE & $0.946(0.011)$ & $0.939(0.010)$ & $0.944(0.005)$ & $0.939(0.004)$ & $0.948(0.007)$ & $0.952(0.001)$ & $0.945(0.005)$ & $0.946(0.021)$ & $0.954(0.001)$ & $0.971(0.004)$ & $0.965(0.004)$ & $0.963(0.009)$ \\
\hline $\mathrm{CO}_{2}$ & $1762(25)$ & 1801(14) & 1739(9) & $1724(6)$ & $1837(15)$ & $1769(15)$ & $1772(41)$ & $1687(53)$ & $1688(5)$ & $1733(8)$ & $1786(6)$ & $1736(49.1)$ \\
\hline $\mathrm{CO}$ & $63.9(13.4)$ & $74.9(13.1)$ & $65.6(5.3)$ & $71.1(4.8)$ & $64.3(8.0)$ & $56.4(1.9)$ & $66.0(6.4)$ & $61.0(23.4)$ & $52.3(1.6)$ & $32.7(4.5)$ & $40.6(4.3)$ & $41.9(9.9)$ \\
\hline $\mathrm{CH}_{4}$ & $1.17(0.51)$ & $1.49(0.28)$ & $1.72(0.33)$ & $1.78(0.20)$ & $0.81(0.49)$ & $1.66(0.30)$ & $1.44(0.38)$ & $2.30(1.35)$ & $1.64(0.31)$ & $0.66(0.26)$ & $1.10(0.31)$ & $1.13(0.49)$ \\
\hline $\mathrm{C}_{2} \mathrm{H}_{2}$ & $0.111(0.038)$ & $0.122(0.076)$ & $0.307(0.111)$ & $0.394(0.115)$ & $0.101(0.037)$ & $0.130(0.025)$ & $0.194(0.125)$ & $0.20(0.12)$ & $0.090(0.036)$ & $0.039(0.004)$ & $0.073(0.023)$ & $0.067(0.026)$ \\
\hline $\mathrm{C}_{2} \mathrm{H}_{4}$ & $0.369(0.251)$ & $0.574(0.138)$ & $0.526(0.130)$ & $0.545(0.068)$ & $0.246(0.116)$ & $0.514(0.121)$ & $0.462(0.128)$ & & $0.344(0.065)$ & $0.163(0.050)$ & $0.371(0.120)$ & $0.293(0.113)$ \\
\hline $\mathrm{C}_{3} \mathrm{H}_{6}$ & $0.132(0.101)$ & $0.208(0.039)$ & $0.136(0.072)$ & $0.093(0.038)$ & $0.074(0.070)$ & $0.200(0.075)$ & $0.141(0.055)$ & $0.43(0.17)$ & $0.100(0.041)$ & $0.045(0.022)$ & $0.146(0.065)$ & $0.097(0.051)$ \\
\hline $\mathrm{CH}_{3} \mathrm{OH}$ & $0.386(0.242)$ & $0.480(0.072)$ & $0.292(0.117)$ & $0.238(0.047)$ & $0.170(0.085)$ & $0.249(0.037)$ & $0.303(0.112)$ & & $0.341(0.066)$ & $0.133(0.039)$ & $0.218(0.078)$ & $0.231(0.105)$ \\
\hline $\mathrm{HCOOH}$ & $0.123(0.099)$ & $0.104(0.030)$ & $0.045(0.022)$ & $0.032(0.002)$ & $0.050(0.047)$ & $0.032(0.010)$ & $0.064(0.039)$ & & $0.051(0.036)$ & $0.040(0.009)$ & $0.035(0.012)$ & $0.042(0.008)$ \\
\hline $\mathrm{CH}_{3} \mathrm{COOH}$ & $0.864(0.524)$ & $0.928(0.148)$ & $0.434(0.098)$ & $0.377(0.012)$ & $0.342(0.169)$ & $0.414(0.084)$ & $0.560(0.263)$ & & $0.506(0.061)$ & $0.366(0.089)$ & $0.407(0.159)$ & $0.426(0.072)$ \\
\hline $\mathrm{HCHO}$ & $0.496(0.349)$ & $0.569(0.188)$ & $0.296(0.077)$ & $0.263(0.050)$ & $0.240(0.167)$ & $0.254(0.036)$ & $0.353(0.142)$ & & $0.264(0.048)$ & $0.134(0.031)$ & $0.198(0.069)$ & $0.199(0.065)$ \\
\hline $\mathrm{C}_{4} \mathrm{H}_{4} \mathrm{O}$ (furan) & $0.142(0.132)$ & $0.116(0.084)$ & $0.051(0.024)$ & $0.036(0.012)$ & $0.064(0.048)$ & $0.048(0.010)$ & $0.076(0.043)$ & & $0.039(0.016)$ & $0.024(0.021)$ & $0.047(0.019)$ & $0.037(0.012)$ \\
\hline $\mathrm{NH}_{3}$ & $0.540(0.190)$ & $0.512(0.242)$ & $0.734(0.431)$ & $0.522(0.103)$ & $0.411(0.250)$ & $0.769(0.164)$ & $0.581(0.140)$ & $.90(1.14)$ & $0.717(0.262)$ & $0.269(0.102)$ & $0.580(0.130)$ & $0.522(0.230)$ \\
\hline NO & $2.466(0.193)$ & $2.506(0.290)$ & $2.260(0.242)$ & $2.060(0.256)$ & $2.311(0.205)$ & $2.327(0.101)$ & $2.322(0.160)$ & & $2.611(0.158)$ & $2.807(0.167)$ & $2.832(0.226)$ & $2.750(0.121)$ \\
\hline $\mathrm{NO}_{2}$ & $1.061(0.474)$ & $0.650(0.140)$ & $0.523(0.103)$ & $0.330(0.008)$ & $0.552(0.096)$ & $0.601(0.169)$ & $0.620(0.242)$ & & $0.790(0.039)$ & $0.566(0.077)$ & $0.496(0.087)$ & $0.617(0.154)$ \\
\hline $\mathrm{NO}_{\mathrm{x}}$ (as $\mathrm{NO}$ ) & $3.158(0.243)$ & $2.930(0.366)$ & $2.601(0.268)$ & $2.276(0.261)$ & $2.672(0.209)$ & $2.719(0.140)$ & $2.726(0.300)$ & $5.11(2.27)$ & $3.126(0.154)$ & $3.176(0.163)$ & $3.156(0.215)$ & $3.153(0.025)$ \\
\hline HONO & $0.345(0.161)$ & $0.442(0.098)$ & $0.230(0.042)$ & $0.189(0.058)$ & $0.170(0.039)$ & $0.171(0.032)$ & $0.258(0.112)$ & & $0.160(0.029)$ & $0.182(0.042)$ & $0.204(0.033)$ & $0.182(0.022)$ \\
\hline $\mathrm{HCN}$ & $0.063(0.048)$ & $0.064(0.036)$ & $0.074(0.025)$ & $0.063(0.006)$ & $0.033(0.016)$ & $0.073(0.009)$ & $0.062(0.015)$ & & $0.072(0.019)$ & $0.024(0.013)$ & $0.049(0.006)$ & $0.048(0.024)$ \\
\hline $\mathrm{HCl}$ & $0.159(0.062)$ & $0.030(0.011)$ & $0.258(0.168)$ & $0.035(0.030)$ & $0.167(0.094)$ & $0.397(0.164)$ & $0.174(0.139)$ & & $0.086(0.032)$ & $0.002(0.007)$ & $0.007(0.012)$ & $0.032(0.047)$ \\
\hline $\mathrm{SO}_{2}$ & $0.545(0.204)$ & $0.641(0.090)$ & $0.902(0.139)$ & $0.743(0.031)$ & $0.559(0.070)$ & $0.693(0.043)$ & $0.681(0.133)$ & & $0.817(0.107)$ & $0.666(0.068)$ & $0.708(0.088)$ & $0.730(0.078)$ \\
\hline $\mathrm{ER}\left(\mathrm{CO}_{2}\right) \Sigma \mathrm{NMOC}^{3}$ & 1.708 & 2.042 & 1.563 & 1.545 & 0.850 & 1.311 & 1.503 & & 1.243 & 0.618 & 1.015 & 0.959 \\
\hline $\mathrm{ER}\left(\mathrm{CO}_{2}\right) \Sigma \mathrm{OVOC}^{3}$ & 1.193 & 1.305 & 0.708 & 0.605 & 0.504 & 0.610 & 0.821 & & 0.770 & 0.405 & 0.533 & 0.570 \\
\hline$\Sigma \mathrm{OVOC} / \Sigma \mathrm{NMOC}^{3}$ & $70 \%$ & $64 \%$ & $45 \%$ & $39 \%$ & $59 \%$ & $47 \%$ & $54 \%$ & & $62 \%$ & $66 \%$ & $53 \%$ & $60 \%$ \\
\hline
\end{tabular}

1 Value in brackets corresponds to $(1 \sigma)$ standard deviation.

2 See Table 1 for fuel codes.

${ }^{3}$ NMOC and OVOC data includes only those species measured by OP-FTIR and are given as molar emission ratios $\left(\mathrm{mmol} \mathrm{mol}^{-1}\right)$.

comparison purposes. The fire-integrated emission factors for all fuels sampled in this study are shown in Table 2 for the southwestern fuels and Table 3 for the southeastern fuels, respectively. These are averages of the replicate samples (three to six replicate measurements for each fuel type, see Table 1). More than 100 other NMOC and inorganic acids were also measured along with the particle emissions, and are being reported separately (including Roberts et al., 2010; Veres et al., 2010; and Warneke et al., 2010). These additional NMOC are often reactive and very important in plume chemistry even though they have only a small effect on the carbon mass balance. A summary of all emission factors, based on both the lab and field measurements will be presented elsewhere.

\subsection{Emission factors of organic compounds}

We first present a comparison of the EFs for the organic species as a function of MCE for the southeastern and southwestern fuels with several other studies that have readily available EF regression data as a function of MCE. The NMOC EFs we measured are shown as a function of MCE in Fig. 3. We also compare our data to the previous studies of McMeeking et al. (2009) (green line), Yokelson et al. (2003) (red line), and Christian et al. (2003) (blue line) where available. McMeeking et al. (2009) describe results from a laboratory study involving similar fuel types to those burned in our study. The Yokelson et al. (2003) study was an aircraft study of nascent plumes in Africa while Christian et al. (2003) was a laboratory study of African and Indonesian fuels.
Methane is the most abundant hydrocarbon emitted from biomass burning (Urbanski et al., 2009). The fit for $\mathrm{EF}\left(\mathrm{CH}_{4}\right)$ as a function of MCE is nearly identical to that presented in Yokelson et al. (2003). Our EF results for ethyne (acetylene, $\mathrm{C}_{2} \mathrm{H}_{2}$ ) are not well correlated with MCE. Several data points show little dependence on MCE and several show increasing $\mathrm{EF}$ as MCE decreases. This may be a consequence of the fact that $\mathrm{C}_{2} \mathrm{H}_{2}$ can be produced by both flaming and smoldering combustion (Lobert et al., 1991). For ethene, with the exception of a single point our data fall near a line similar to those of Yokelson et al. (2003) and Christian et al. (2003). The regression line for propene, with an $R^{2}$ of 0.50 , has a lower slope and intercept than that of McMeeking et al. (2009).

Biomass burning is an important source of oxygenated volatile organic compounds (OVOC). All oxygenated organic species detected by OP-FTIR show a linear dependence on MCE characteristic of smoldering combustion, with $R^{2}$ ranging from 0.58 to 0.73 . Our EFs agree quite well with results previously published in the literature. Our emission factors for $\mathrm{HCOOH}$ show a reasonable correlation with $\operatorname{MCE}\left(R^{2}=0.66\right)$. Note that the $\mathrm{HCOOH}$ emission factors of Christian et al. (2003), Yokelson et al. (1999) and Yokelson et al. (2003) in Fig. 3 and Table 3 have been lowered by a factor of 2.1 due to previous underestimation of the $\mathrm{HCOOH}$ absorption line parameters (Perrin and Vander Auwera, 2007). From Table 2 and Table 3, with the exception of the understory hardwood sample of Camp Lejeune, the $\mathrm{HCOOH}$ emission factors are higher for the southeastern fuel types than the southwestern fuels (see also Veres et al., 2010).

Warneke et al. (2010) reported that $25-50 \%$ of the mass of NMOC detectable by PTR-MS and PIT-MS remains 


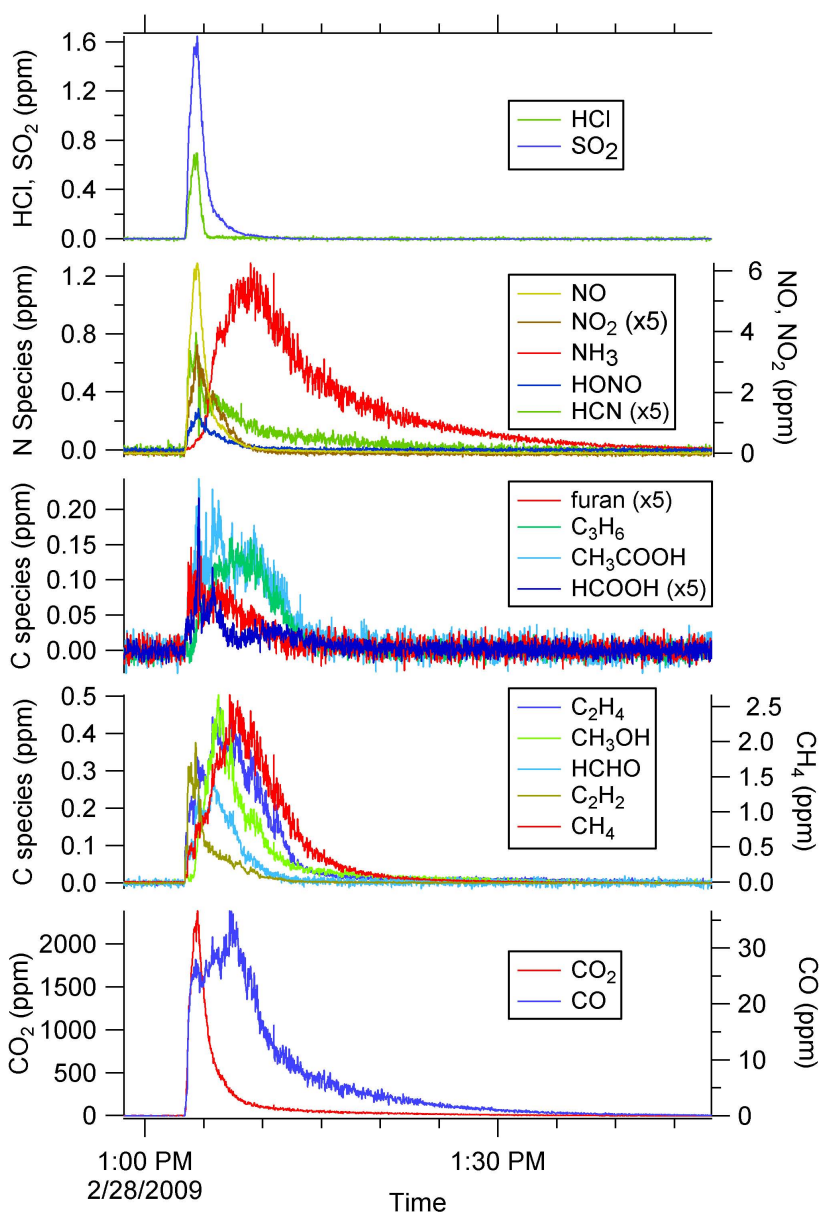

Fig. 2. Excess mixing ratios of 18 compounds over time for a typical fire as measured quantitatively by OP-FTIR from a California sage fuel bed.

unidentified by any technique in these fires. With the OPFTIR, which has roughly equal sensitivity to non-methane hydrocarbons (NMHC) and OVOC, we report only three NMHC species: $\mathrm{C}_{2} \mathrm{H}_{2}, \mathrm{C}_{2} \mathrm{H}_{4}$, and $\mathrm{C}_{3} \mathrm{H}_{6}$, with all other NMHC species being below the detection limits. Tables 2 and 3 also show the total OP-FTIR-identified gas-phase, NMOC, and OVOC molar emission ratios with respect to $\mathrm{CO}_{2}$. The contribution of total OVOC species to the total NMOC ranged from 39 to $79 \%$, with a study average of $61 \%$. On average, the southeastern fuels had a higher OVOC/NMOC ratio than the southwestern $(69 \%$ and 56\%, respectively). When the OP-FTIR data is combined with PTR-MS and PIT-MS (Warneke et al., 2010) the OVOC/NMOC ratio remains essentially unchanged: $70 \%$ and $58 \%$ for the southeastern and southwestern fuels, respectively. The low molecular weight OVOC species measured by OP-FTIR ( $\mathrm{HCHO}, \mathrm{HCOOH}, \mathrm{CH}_{3} \mathrm{OH}$, and $\mathrm{CH}_{3} \mathrm{COOH}$ ) account for approximately $75 \%$ of the identified OVOC on a molar basis. Whole air sampling combined with preconcentration and GC analysis can provide lower detection limits for NMHC than FTIR. In Yokelson et al. (2008), when PTR-MS and whole-air sampling were co-deployed with FTIR there was enhanced capability to detect non-methane hydrocarbon (NMHC) species and the OVOC/NMOC ratio observed was $\sim 80 \%$ in the smoke from the burning of various tropical fuels. The NMHC compounds, particularly the unsaturated species, are important in plume chemistry due to their high reactivity with $\mathrm{OH}$, while $\mathrm{OVOC}$ react with $\mathrm{OH}$ and can also undergo photolysis (Singh et al., 1995).

\subsection{Emissions of nitrogen-containing species}

Biomass burning is an important atmospheric source of reactive nitrogen species, primarily $\mathrm{NH}_{3}$ and $\mathrm{NO}_{\mathrm{x}}\left(=\mathrm{NO}+\mathrm{NO}_{2}\right)$. In addition, other gas-phase nitrogen emissions include $\mathrm{N}_{2}$, $\mathrm{HONO}$, nitrous oxide $\left(\mathrm{N}_{2} \mathrm{O}\right), \mathrm{HCN}$, acetonitrile $\left(\mathrm{CH}_{3} \mathrm{CN}\right)$ and isocyanic acid ( $\mathrm{HNCO}$ ). $\mathrm{CH}_{3} \mathrm{CN}$ and $\mathrm{HCN}$ are likely emitted almost exclusively by fires and are useful as biomass burning marker compounds (Crounse et al., 2009; de Gouw et al., 2003; Li et al., 2000; Yokelson et al., 2007b).

The emissions of the nitrogen-containing species observed here are dependent on the fuel nitrogen content. For example, the emission factors of $\mathrm{NO}_{\mathrm{x}}$ as a function of both MCE and fuel nitrogen content are shown in Fig. 4a for selected samples from Camp Lejeune. $\mathrm{NO}_{\mathrm{x}}$ is a component of flaming combustion so it is expected to have a higher EF with increasing MCE. Figure $4 \mathrm{a}$ shows that $\mathrm{EF}\left(\mathrm{NO}_{\mathrm{x}}\right)$ actually decreases with increasing MCE but increases with increasing fuel nitrogen content. Figure $4 \mathrm{~b}$ shows the correlation of MCE with $\mathrm{EF}\left(\mathrm{NO}_{\mathrm{x}}\right)$ normalized to fuel nitrogen, which is consistent with $\mathrm{NO}_{\mathrm{x}}$ being produced by flaming combustion. From the figure, $\mathrm{EF}\left(\mathrm{NO}_{\mathrm{x}}\right)$ appears to be driven more by fuel nitrogen content than MCE, a finding consistent with other studies (Andreae and Merlet, 2001; McMeeking et al., 2009). A similar dependence of emissions of carbon-containing compounds on fuel carbon content is unlikely to be significant due to the low variability in fuel carbon content among the samples. For all samples in this study, the fuel nitrogen content varied from $0.44 \%$ to $1.3 \%$ ( $\sim 300 \%$ variation) while the carbon content varied from $48.5 \%$ to $55 \%$ ( 13\% variation). Also, when known, the carbon fraction of the fuel is accounted for in the EF calculation. This result shows that emission factors of compounds containing elements other than carbon (e.g. N, S, Cl) may be highly dependent on the elemental composition of the fuel.

For the reactive nitrogen species, $\mathrm{NO}_{\mathrm{x}}$ and $\mathrm{NH}_{3}$, Goode et al. (1999), Goode et al. (2000), and McMeeking et al. (2009) plotted $\Delta \mathrm{NH}_{3} / \Delta \mathrm{NO}_{\mathrm{x}}$ vs. MCE compiled from several studies. While our results are similar to those of Goode et al. (2000) and the Flame 2 points of McMeeking et al. (2009), there is a large amount of scatter among the compiled data.

Using the measured nitrogen content of the fuels, we calculated the fire-integrated fraction of the fuel nitrogen accounted for by each species measured by OP-FTIR. Two other species not measured by OP-FTIR were included in this 

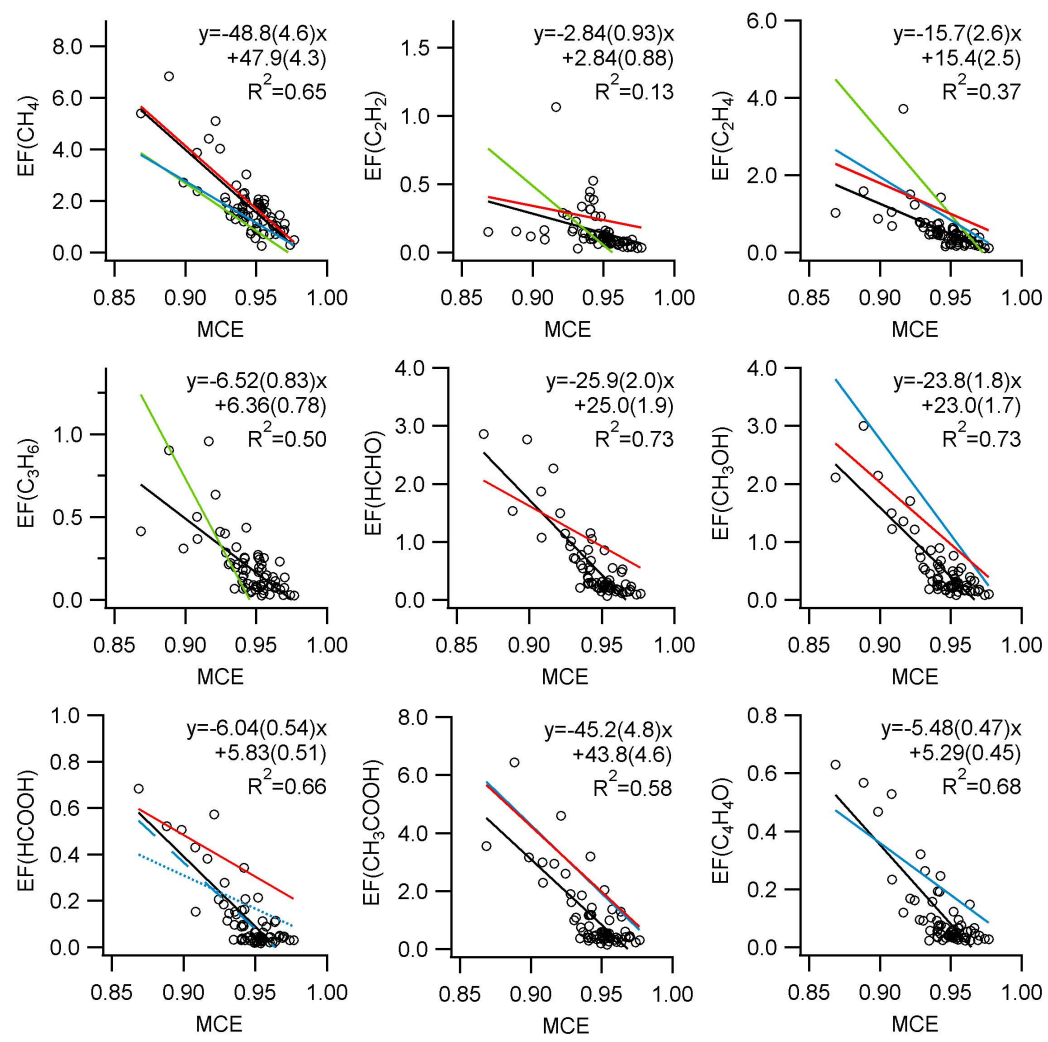

Fig. 3. Emission factors $\left(\mathrm{g} \mathrm{kg}^{-1}\right)$ plotted as a function of modified combustion efficiency (MCE) for carbon-containing gas-phase species measured by OP-FTIR for the southeastern and southwestern fuels. The quantities in brackets represent the $1 \sigma$ standard error of the slope and y-intercept. Also shown here are the lines of best fit from several studies (black line - this study; red line - Yokelson et al. (2003); green line - McMeeking et al. (2009); blue line - Christian et al. (2003). The blue lines for $\mathrm{HCOOH}$ in the lower left plot are unpublished results from the data of Christian et al. (2003) for African fuels (dotted line) and Indonesian fuels (dashed line).

nitrogen-balance calculation. While acetonitrile $\left(\mathrm{CH}_{3} \mathrm{CN}\right)$ has strong spectral features, it is not measurable by OPFTIR under these atmospheric conditions due to the spectral overlap of very strong water lines. However, $\mathrm{CH}_{3} \mathrm{CN}$ was measured by PTR-MS (Warneke et al., 2010) and is included in this discussion. We also included isocyanic acid (HNCO), observed during flaming combustion by NI-PTCIMS (Roberts et al., 2010; Veres et al., 2010). Considering those gases measured by the OP-FTIR as well as $\mathrm{CH}_{3} \mathrm{CN}$ and $\mathrm{HNCO}$ and knowledge of the nitrogen content of the fuels, we present the results of the nitrogen balance in Fig. 5, which shows the fraction of the species emitted compared to the available fuel nitrogen as a function of fuel type. The contribution of all these measured gas-phase species accounts for $16 \%$ to $43 \%$ of the total fuel nitrogen, varying by fuel type.

From Fig. 5, the fractional contributions of $\mathrm{NH}_{3}, \mathrm{HCN}$, $\mathrm{CH}_{3} \mathrm{CN}$, and $\mathrm{HNCO}$ are higher and more variable for the samples of the southeastern fuels. The HCN fraction ranges from $\sim 0.4-6 \%$ for the southeastern fuels and is $<0.33 \%$ for the southwestern fuels. It is highest for the pine litter samples of Fort Benning - the sample with the lowest average MCE. In general, the contribution of HONO also appears to be higher for the southeastern fuels. Although $\mathrm{N}_{2} \mathrm{O}$ was defi- nitely observed by our OP-FTIR instrument it is not included in this calculation due to difficulties with quantification at our selected spectral resolution in smoke, where it is masked by the presence of very high $\mathrm{CO}$ and $\mathrm{CO}_{2}$. However, previous FTIR work at higher resolution suggests that $\mathrm{N}_{2} \mathrm{O}$ is a minor product (Griffith et al., 1991). Based on the $\mathrm{N}_{2} \mathrm{O}$ emission data from Andreae and Merlet (2001), Griffith et al. (1991), and Hao et al. (1991), we estimate that the $\mathrm{N}_{2} \mathrm{O}$ contribution to the nitrogen balance would be roughly $<1-3 \%$ of the fuel nitrogen.

From Fig. 5, there is a loose correlation between the unaccounted nitrogen and MCE $(r=-0.71)$. Gas-phase molecular nitrogen $\left(\mathrm{N}_{2}\right)$ typically represents a significant fraction of the nitrogen emissions from biomass burning (Kuhlbusch et al., 1991), especially from flaming combustion. Using the data of Kuhlbusch et al. (1991), Goode et al. (1999) estimated a $\mathrm{N}_{2}$ emission fraction (compared to the nitrogen content of the fuel) of $36 \pm 13 \%$ for MCE values near 0.91 and $45 \pm 5 \%$ for MCE values around 0.95 , the typical range of MCE values observed in our study. By including the MCE-dependent contribution of $\mathrm{N}_{2}$, we account for approximately 60 to $77 \%$ of all fuel nitrogen. 
Table 3. Emission factors ${ }^{1}\left(\mathrm{~g} \mathrm{~kg}^{-1}\right)$ of gas-phase species for southeastern and additional fuels.

\begin{tabular}{|c|c|c|c|c|c|c|c|c|c|c|c|}
\hline & $\begin{array}{l}\text { FB } \\
\text { lit }^{2}\end{array}$ & $\begin{array}{l}\mathrm{CL} \\
1 \mathrm{yr}\end{array}$ & $\begin{array}{l}\mathrm{CL} \\
2 \mathrm{yr}\end{array}$ & $\begin{array}{l}\mathrm{CL} \\
\text { poc }\end{array}$ & $\begin{array}{l}\text { CL } \\
\text { cuh }\end{array}$ & $\begin{array}{l}\text { CL } \\
\text { uh }\end{array}$ & $\begin{array}{r}\text { Camp Lejeune } \\
\text { average }\end{array}$ & $\begin{array}{r}\text { Camp Lejeune } \\
\text { (Yokelson et al., 1999) }\end{array}$ & $\begin{array}{l}\text { AK } \\
\text { duf }\end{array}$ & $\begin{array}{r}\text { MT } \\
\text { spr }\end{array}$ & $\begin{array}{l}\text { MT } \\
\text { ppn }\end{array}$ \\
\hline MCE & $0.894(0.017)$ & $0.934(0.015)$ & $0.927(0.006)$ & $0.953(0.011)$ & $0.959(0.003)$ & $0.954(0.012)$ & $0.945(0.014)$ & $0.926(0.001)$ & 0.827 & 0.934 & 0.959 \\
\hline $\mathrm{CO}_{2}$ & $1710(39)$ & $1859(42)$ & $1780(19)$ & $1874(27)$ & $1891(7)$ & $1739(23)$ & $1828.6(66)$ & $1677(8)$ & 1219 & 1785 & 1856 \\
\hline $\mathrm{CO}^{-}$ & $128.6(19.8)$ & $84.0(18.2)$ & $88.8(7.4)$ & $59.4(13.7)$ & $51.9(3.3)$ & $53.6(13.7)$ & $67.5(17.5)$ & $85.9(2.7)$ & 162 & 80.6 & 51.0 \\
\hline $\mathrm{CH}_{4}$ & $4.25(1.87)$ & $3.25(1.07)$ & $3.47(1.35)$ & $1.69(0.55)$ & $1.55(0.44)$ & $1.35(0.37)$ & $2.26(1.01)$ & $4.46(1.03)$ & 9.60 & 4.00 & 1.21 \\
\hline $\mathrm{C}_{2} \mathrm{H}_{2}$ & $0.138(0.029)$ & $0.527(0.486)$ & $0.207(0.091)$ & $0.098(0.022)$ & $0.065(0.012)$ & $0.088(0.010)$ & $0.197(0.192)$ & & 0.112 & 0.565 & 0.085 \\
\hline $\mathrm{C}_{2} \mathrm{H}_{4}$ & $1.048(0.339)$ & $1.969(1.556)$ & $1.059(0.385)$ & $0.450(0.143)$ & $0.280(0.070)$ & $0.428(0.097)$ & $0.837(0.700)$ & & 1.73 & 2.14 & 0.502 \\
\hline $\mathrm{C}_{3} \mathrm{H}_{6}$ & $0.500(0.236)$ & $0.551(0.364)$ & $0.442(0.136)$ & $0.176(0.088)$ & $0.108(0.025)$ & $0.162(0.056)$ & $0.288(0.196)$ & 1.26 & 1.40 & 0.721 & 0.201 \\
\hline $\mathrm{CH}_{3} \mathrm{OH}$ & $1.994(0.687)$ & $0.868(0.424)$ & $1.161(0.404)$ & $0.667(0.294)$ & $0.224(0.036)$ & $0.521(0.112)$ & $0.688(0.353)$ & 2.03 & 4.07 & 1.62 & 0.135 \\
\hline $\mathrm{HCOOH}$ & $0.460(0.194)$ & $0.227(0.145)$ & $0.280(0.197)$ & $0.224(0.115)$ & $0.033(0.011)$ & $0.119(0.036)$ & $0.177(0.099)$ & $0.59^{5}$ & 0.917 & 0.393 & 0.079 \\
\hline $\mathrm{CH}_{3} \mathrm{COOH}$ & $3.688(1.605)$ & $1.853(0.951)$ & $2.743(1.288)$ & $2.119(1.045)$ & $0.337(0.083)$ & $1.276(0.106)$ & $1.666(0.911)$ & 3.11 & 9.28 & 2.17 & 0.188 \\
\hline $\mathrm{HCHO}$ & $2.024(0.777)$ & $1.277(0.899)$ & $1.088(0.312)$ & $0.846(0.313)$ & $0.209(0.045)$ & $0.633(0.203)$ & $0.811(0.415)$ & $2.25(0.10)$ & 2.28 & 1.91 & 0.512 \\
\hline $\mathrm{C}_{4} \mathrm{H}_{4} \mathrm{O}$ (furan) & $0.486(0.152)$ & $0.091(0.025)$ & $0.132(0.039)$ & $0.124(0.067)$ & $0.041(0.022)$ & $0.139(0.059)$ & $0.105(0.040)$ & & 1.25 & 0.228 & 0.119 \\
\hline $\mathrm{NH}_{3}$ & $0.952(0.337)$ & $0.942(0.212)$ & $1.037(0.162)$ & $0.472(0.132)$ & $0.354(0.006)$ & $0.520(0.162)$ & $0.665(0.304)$ & 0.56 & 3.41 & 1.46 & 0.276 \\
\hline NO & $1.860(0.377)$ & $1.980(0.131)$ & $2.257(0.343)$ & $1.148(0.115)$ & $1.365(0.063)$ & $1.849(0.034)$ & $1.720(0.454)$ & & 0.738 & 1.74 & 2.05 \\
\hline $\mathrm{NO}_{2}$ & $0.932(0.403)$ & $1.028(0.256)$ & $1.233(0.311)$ & $1.346(0.220)$ & $0.623(0.098)$ & $0.886(0.040)$ & $1.023(0.286)$ & & 0.232 & 1.58 & 0.865 \\
\hline $\mathrm{NO}_{\mathrm{X}}$ (as $\mathrm{NO}$ ) & $2.468(0.490)$ & $2.651(0.053)$ & $3.061(0.261)$ & $2.025(0.079)$ & $1.772(0.126)$ & $2.427(0.033)$ & $2.387(0.509)$ & & 0.890 & 2.77 & 2.61 \\
\hline HONO & $0.241(0.052)$ & $0.603(0.231)$ & $0.515(0.090)$ & $0.402(0.073)$ & $0.146(0.026)$ & $0.425(0.033)$ & $0.418(0.172)$ & & 0.037 & 0.620 & 0.194 \\
\hline $\mathrm{HCN}$ & $0.650(0.163)$ & $0.233(0.123)$ & $0.337(0.116)$ & $0.106(0.060)$ & $0.041(0.005)$ & $0.104(0.058)$ & $0.164(0.119)$ & & 1.74 & 0.316 & 0.105 \\
\hline $\mathrm{HCl}$ & $0.094(0.045)$ & $-0.012(0.023)$ & $0.032(0.012)$ & $0.177(0.072)$ & $0.057(0.016)$ & $0.045(0.059)$ & $0.060(0.071)$ & & bdl $^{4}$ & 0.046 & 0.087 \\
\hline $\mathrm{SO}_{2}$ & $1.547(0.324)$ & $1.095(0.099)$ & $1.435(0.176)$ & $0.866(0.081)$ & $0.437(0.013)$ & $0.868(0.156)$ & $0.940(0.365)$ & & 2.31 & 1.50 & 0.807 \\
\hline $\mathrm{ER}\left(\Sigma \mathrm{NMOC} / \mathrm{CO}_{2}\right)^{3}$ & 6.766 & 4.983 & 4.513 & 2.703 & 0.837 & 2.171 & 3.041 & & 17.88 & 6.84 & 1.28 \\
\hline $\mathrm{ER}\left(\Sigma \mathrm{OVOC} / \mathrm{CO}_{2}\right)$ & 5.361 & 2.529 & 3.121 & 2.138 & 0.486 & 1.601 & 1.975 & & 14.29 & 4.00 & 0.661 \\
\hline$\Sigma$ OVOC/ $\Sigma$ NMOC & $79 \%$ & $51 \%$ & $69 \%$ & $79 \%$ & $58 \%$ & $74 \%$ & $66 \%$ & & $80 \%$ & $58 \%$ & $52 \%$ \\
\hline
\end{tabular}

1 Value in brackets corresponds to $(1 \sigma)$ standard deviation.

2 See Table 1 for fuel codes.

${ }^{3}$ NMOC and OVOC data includes only those species measured by OP-FTIR and are given as molar emission ratios ( $\mathrm{mmol} \mathrm{mol}^{-1}$ ).

${ }^{4}$ bdl - below detection limit.

5 The $\mathrm{EF}(\mathrm{HCOOH})$ of Yokelson et al. (1999) has been decreased by a factor of 2.1 (see text).
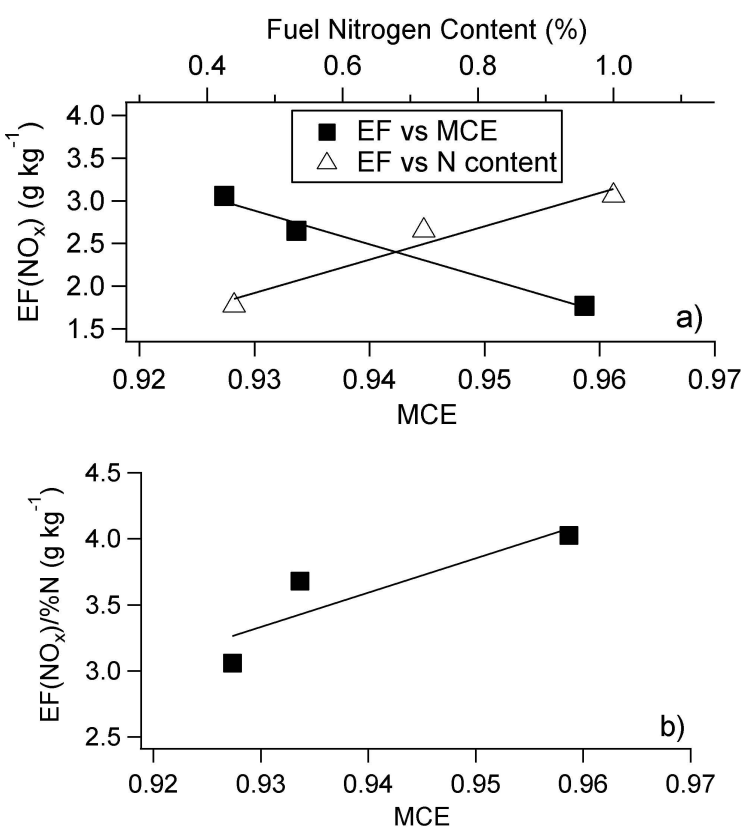

Fig. 4. Dependence of $\mathrm{EF}\left(\mathrm{NO}_{\mathrm{x}}\right)$ on fuel nitrogen content and $\mathrm{MCE}$ for chipped understory hardwood, one-year rough and two-year rough from Camp Lejeune. (a) $\mathrm{EF}\left(\mathrm{NO}_{\mathrm{x}}\right)$ as a function of fuel nitrogen content and MCE. (b) $\mathrm{EF}\left(\mathrm{NO}_{\mathrm{x}}\right)$ normalized by fuel nitrogen content as a function of MCE.
Ionic nitrogen species in the particulate-phase $\left(\mathrm{NH}_{4}^{+}\right.$, $\mathrm{NO}_{3}^{-}, \mathrm{NO}_{2}^{-}$) are expected to be a minor component of the nitrogen balance. McMeeking et al. (2009) observed $\mathrm{NO}_{3}^{-}$emission factors ranging from 0.01 to $2.9 \mathrm{~g} \mathrm{NO}_{3}^{-} \mathrm{kg}^{-1}$ dry fuel $\left(0.002\right.$ to $\left.0.65 \mathrm{~g} \mathrm{~N} \mathrm{~kg}^{-1}\right)$ with a study average of $0.2 \pm 0.4 \mathrm{~g} \mathrm{NO}_{3}^{-} \mathrm{kg}^{-1}$ dry fuel $\left(0.05 \pm 0.09 \mathrm{~g} \mathrm{~N} \mathrm{~kg}^{-1}\right)$ and this work included several vegetation types similar to our study. In fact, they found particulate-phase $\mathrm{NO}_{3}^{-}$to be insignificant for the chaparral fuel type. Their value for particulate-phase $\mathrm{NH}_{4}^{+}$was $0.1 \pm 0.1 \mathrm{~g} \mathrm{NH}_{4}^{+} \mathrm{kg}^{-1}$ dry fuel $\left(0.08 \pm 0.08 \mathrm{~g} \mathrm{~N} \mathrm{~kg}^{-1}\right)$. For the chaparral fuels used in our study, this is roughly equivalent to $<1 \%$ of the fuel nitrogen.

Although we determined the nitrogen content of the ash, the mass of the ash was not determined for all fires. For several of the burns, the lighter ash was often entrained and lofted with the smoke up the stack or was deposited off the fuel bed. Lobert et al. (1991) found that the ash nitrogen accounted for $9.94 \%$ of the fuel nitrogen by weight on average, with a wide range of $1.75-46.0 \%$, while Kuhlbusch et al. (1996) observed that $26 \pm 11 \%$ of the fuel nitrogen remained in the ash.

We account for roughly 16 to $43 \%$ of the available fuel nitrogen as gaseous emissions of $\mathrm{NO}_{\mathrm{x}}, \mathrm{NH}_{3}, \mathrm{HONO}, \mathrm{HCN}$, $\mathrm{CH}_{3} \mathrm{CN}$, and $\mathrm{HNCO}$. Most of the remainder of the nitrogen is likely emitted as $\mathrm{N}_{2}$ while some nitrogen remains in the ash. The many other gas-phase nitrogen species in smoke likely account for only a small fraction of the fuel nitrogen. 


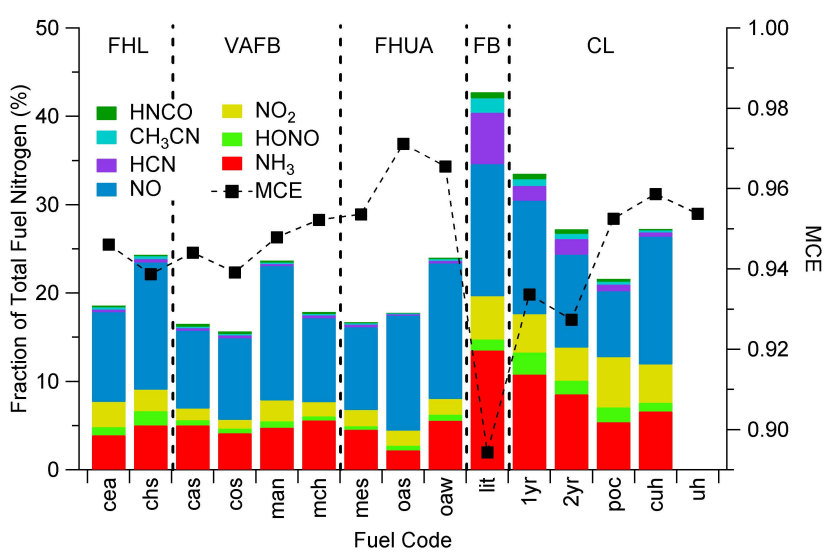

Fig. 5. Contribution of gas-phase nitrogen-containing species to the nitrogen balance. The inclusion of modified combustion efficiency (MCE) shows an anticorrelation between total nitrogen accounted for and MCE.

\subsection{Detection of HONO}

Gas-phase nitrous acid (HONO) was observed in these fires by NI-PT-CIMS (peak at $\mathrm{m} / \mathrm{z}$ 46) (Roberts et al., 2010; Veres et al., 2010) and then confirmed by analysis of the OP-FTIR spectra. Our confirmation of the presence of HONO is illustrated in Fig. 6, which shows the residual OP-FTIR spectrum after removal of the other species that absorb in the same spectral region, excluding HONO. This experimental residual spectrum is compared to a quantitative HONO reference spectrum from the PNNL-SERDP quantitative IR database (Sharpe et al., 2004; Johnson et al., 2010). An in-depth intercomparison of the HONO results from these two measurement techniques is published elsewhere (Roberts et al., 2010; Veres et al., 2010). For all these fires, the two techniques agreed within $20 \%$, well within the associated instrumental uncertainties.

Since HONO can be formed on surfaces, we briefly examined the possibility of heterogeneous formation of HONO on the walls of the stack. Due to constraints on the maximum flow rate up the stack on days when the outside air temperature was lower than $-5^{\circ} \mathrm{C}$, some fires were sampled with roughly 3 times lower flow rate up the stack. This low flow rate increased the residence time within the stack from approximately $5 \mathrm{~s}$ to $17 \mathrm{~s}$ for those fires. Analysis of the HONO results as a function of flow rate showed no flow rate dependence suggesting that heterogeneous gas/wall reactions were likely not a large source of HONO in this experiment.

HONO is emitted during flaming combustion, as can be seen in Fig. 2 since it is co-emitted with $\mathrm{CO}_{2}$. To account for the variability in the nitrogen content of the fuels, it is useful to compare the emission ratio of $\Delta \mathrm{HONO}$ to $\Delta \mathrm{NO}_{\mathrm{x}}$, which is also emitted during the flaming phase. Figure 7 shows the results of the OP-FTIR analysis for the fire-integrated emission ratio of $\Delta \mathrm{HONO} / \Delta \mathrm{NO}_{\mathrm{x}}$. Of the western fuels, the

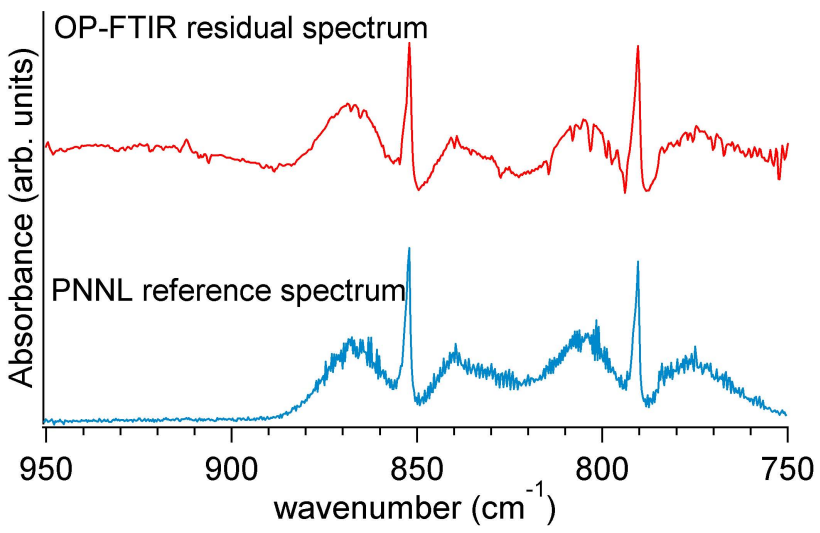

Fig. 6. Spectral confirmation of the presence of HONO in laboratory biomass fires. The upper spectrum is the residual of an actual OP-FTIR spectrum after quantification and subtraction of all species that absorb in this spectral region with HONO omitted from the fit. The lower blue trace is the HONO reference absorption spectrum provided by Pacific Northwest National Laboratories (Sharpe et al., 2004), de-resolved to match the OP-FTIR resolution (there are a few water peaks remaining in the residual spectrum due to its variability and high concentration).

chamise/scrub oak showed the highest $\Delta \mathrm{HONO} / \Delta \mathrm{NO}_{\mathrm{x}}$ ratios. In general, the fuels from the southeast (Camp Lejeune) have higher $\Delta \mathrm{HONO} / \Delta \mathrm{NO}_{\mathrm{x}}$ emission ratios, and as seen also in Table 2 and Table 3, the highest HONO emission factors. The study-wide HONO emission factors ranged from 0.15 to $0.60 \mathrm{~g} \mathrm{HONO} \mathrm{kg}^{-1}$ dry fuel or $1.0 \pm 0.6 \%$ of the fuel nitrogen. It is difficult to assess a trend of $\Delta \mathrm{HONO} / \Delta \mathrm{NO}_{\mathrm{x}}$ for the various fuel types since the emissions may depend on many factors, such as fuel nitrogen content, moisture content, MCE, and the components of the vegetation that were consumed in a particular fire (e.g. leafy or woody material). The $\Delta \mathrm{HONO} / \Delta \mathrm{NO}_{\mathrm{x}}$ ratios range from 0.025 to 0.20 . The large error bars for some of the points on the graph are due to variability from fire-to-fire and do not signify a measurement error.

HONO has been measured previously from biomass burning, both in a laboratory study of southern Africa biomass fires (Keene et al., 2006) and in the field (Yokelson et al., 2007a, 2009) during airborne experiments in Brazil and in the Yucatan Peninsula of Mexico. Keene et al. (2006) observed $\Delta \mathrm{HONO} / \Delta \mathrm{NO}_{\mathrm{x}}$ ratios (50th percentile) for African samples of grass (0.048), shrubs (0.23), branches (0.067), and litter (0.11). Figure 8 shows the results from these studies as a function of altitude, a rough proxy for plume age in this case. The point representing the Keene et al. (2006) study is the average of those fuel types similar to ours (grass, litter, shrubs, and branches). The $\Delta \mathrm{HONO} / \Delta \mathrm{NO}_{\mathrm{x}}$ results in our study are lower on average than those of the laboratory study of Keene et al. (2006) but are of similar magnitude. Keene et al. (2006) also sampled emissions from agricultural waste, charcoal, and dung burning with $\Delta \mathrm{HONO} / \Delta \mathrm{NO}_{\mathrm{x}}$ 


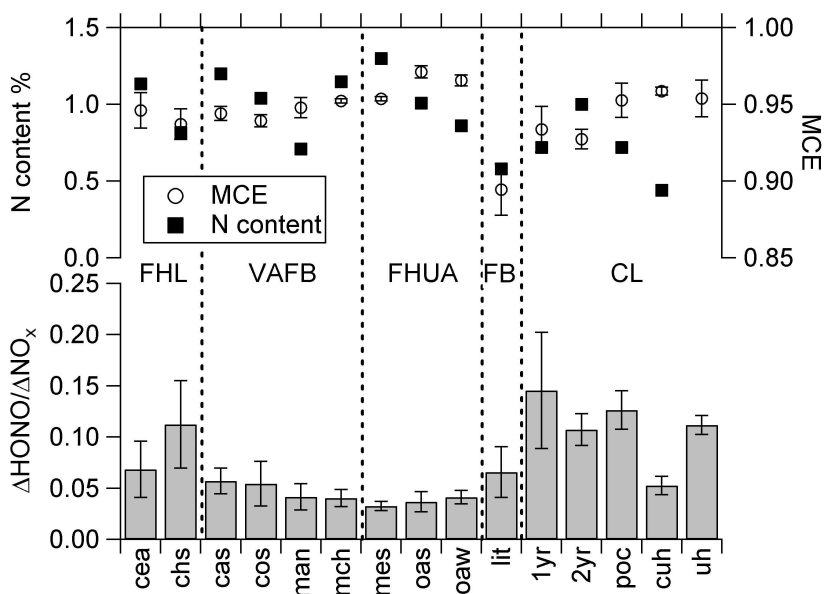

Fig. 7. $\Delta \mathrm{HONO} / \Delta \mathrm{NO}_{\mathrm{x}}$ molar emission ratios for various fuel types. The fuel types are ordered from west to east from left to right. MCE (circles) and fuel nitrogen content fraction (squares) are shown in the upper portion of the plot. See Table 1 for fuel descriptions.

values of $0.11,0.068$, and 0.30 , respectively. The variation in $\Delta \mathrm{HONO} / \Delta \mathrm{NO}_{\mathrm{x}}$ ratios of these two studies are likely due to a dependence on fuel type. The trend of the data points for those samples taken at higher altitudes in Fig. 8 shows a decrease in $\triangle \mathrm{HONO} / \Delta \mathrm{NO}_{\mathrm{x}}$ as altitude increases, although it should be noted that some of these data points correspond to different fires of different fuel types. For the Caltech CIMS samples of the crop residue fire \#2 (Yokelson et al., 2009) there is a definite decreasing trend in $\Delta \mathrm{HONO} / \Delta \mathrm{NO}_{\mathrm{x}}$ as altitude increases, signifying loss of HONO likely due to rapid photolysis as these airborne measurements were made during midday hours. The HONO could actually be decreasing more rapidly than shown since $\mathrm{NO}_{\mathrm{x}}$ is also being lost by conversion into the relatively non-reactive $\mathrm{NO}_{\mathrm{y}}$ compounds such as $\mathrm{HNO}_{3}$ and peroxyacetyl nitrate (PAN).

Several recent studies have modeled photochemical $\mathrm{O}_{3}$ production in young plumes (Trentmann et al., 2005; Alvarado and Prinn, 2009; Alvarado et al., 2009). These models better replicated the experimentally observed rapid formation of $\mathrm{O}_{3}$ by including a source of $\mathrm{HONO}$ as a source of $\mathrm{OH}$. HONO rapidly photolyzes to form $\mathrm{OH}$ and $\mathrm{NO}$ with a daytime photolytic lifetime on the order of 10 to $20 \mathrm{~min}$ (Finlayson-Pitts and Pitts, 2000). The mechanisms of in situ atmospheric HONO formation, including in smoke plumes, are not fully understood. It is most often thought of as a product of heterogeneous reactions involving $\mathrm{NO}_{2}$ and water (Gherman et al., 2007). For example, some of the proposed heterogeneous formation mechanisms of HONO include formation on soot aerosol particles (Kalberer et al., 1999; Kleffmann et al., 1999; Stadler and Rossi, 2000), humic acid aerosol (Stemmler et al., 2007) and secondary organic aerosol (Bröske et al., 2003). In contrast, our study

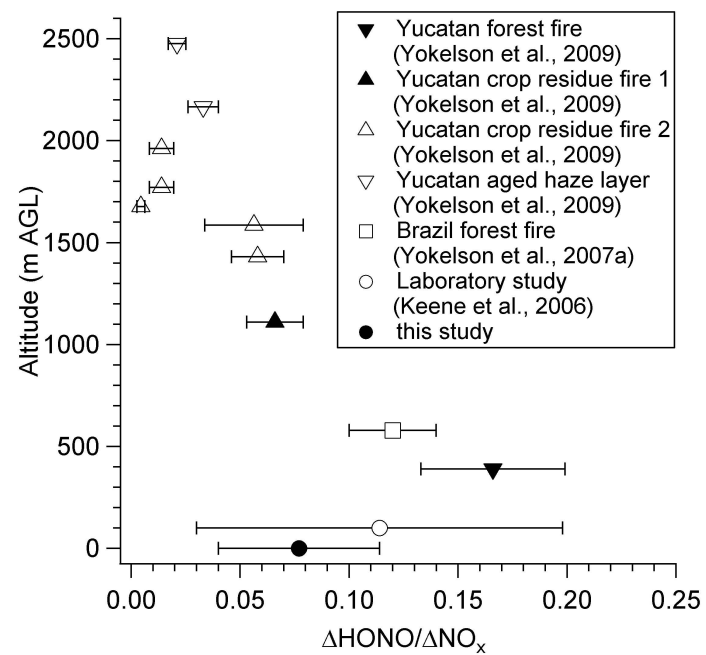

Fig. 8. Molar emission ratio of $\Delta \mathrm{HONO} / \Delta \mathrm{NO}_{\mathrm{x}}$ as a function of altitude for various studies. The error bars represent the $1 \sigma$ standard deviation. Note that the data of our study and that of Keene et al. (2006) are laboratory studies but are offset here for clarity. The data point for Keene et al. (2006) was recalculated including only their data for the grass, shrub, litter, and branch fuel types.

suggests that HONO is also a direct combustion product, which is also consistent with earlier work on other combustion sources (Finlayson-Pitts and Pitts, 2000). These data will be useful in future models to better simulate the secondary processes within biomass burning plumes such as ozone and aerosol formation.

\subsection{Emissions of $\mathrm{HCl}$}

A commonly observed species in our study was gas-phase $\mathrm{HCl}$. Hydrogen chloride was observed during flaming combustion, and from observations of the fire videos, its emission appears correlated to flaming combustion of leafy material. Chloride plays a role in many aspects of plant metabolism including photosynthesis in the green portions of a plant which are principally foliage. The chloride content of biomass is extremely variable $\left(0.009-20 \mathrm{~g} \mathrm{~kg}^{-1}\right.$ dry weight) (Table 4 of Lobert et al., 1999; Marschner, 1986). The emission factors for $\mathrm{HCl}(\mathrm{EF}(\mathrm{HCl}))$ are shown in Fig. 9 by fuel location and type and as expected they vary greatly (a factor of $\sim 200$ ) from $\sim 0.002 \pm 0.007$ to $0.397 \pm 0.164 \mathrm{~g} / \mathrm{kg}$ with one fuel type (AK duff) being below the detection limit. The error bars are the $(1 \sigma)$ fire-to-fire variation for each fuel type. From the figure, the highest $\mathrm{EF}(\mathrm{HCl})$ were observed for those vegetation types containing leafy components which is consistent with the video evidence for production of $\mathrm{HCl}$ during leaf combustion in these fires. Some of the variation in $\mathrm{EF}(\mathrm{HCl})$ depended on whether foliage was burned. Keene et al. (2006) also reported highly variable $\mathrm{EF}(\mathrm{HCl})$ ranging from 0.005 (litter) to 0.188 (grass) $\mathrm{g} / \mathrm{kg}$. To our knowledge, these two studies represent all of the available emission 


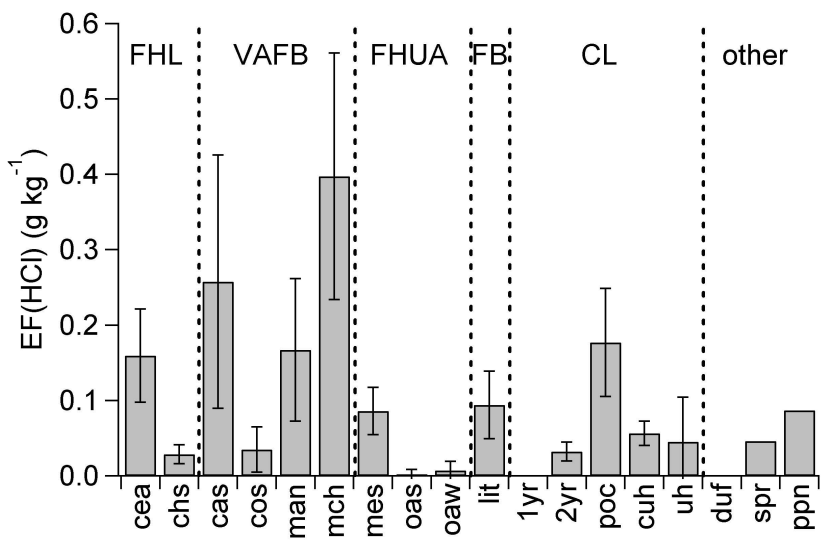

Fig. 9. $\mathrm{HCl}$ emission factors by fuel type. See Table 1 for fuel descriptions.

factor measurements for $\mathrm{HCl}$ from biomass burning. Andreae and Merlet (2001) list EF for global biomass burning for only one chlorine containing compound, methyl chloride $\left(\mathrm{CH}_{3} \mathrm{Cl}\right)$. Lobert et al. (1999) assumed $\mathrm{CH}_{3} \mathrm{Cl}$ was the main $\mathrm{Cl}$-containing emission from biomass burning in their global reactive chlorine emissions inventory and did not include biomass burning emissions of $\mathrm{HCl}$ in that study. The $\mathrm{EF}\left(\mathrm{CH}_{3} \mathrm{Cl}\right)$ recommended by Andreae and Merlet (2001) range from $0.01-0.075 \mathrm{~g} / \mathrm{kg}$ and are similar to the lower half of $\mathrm{EF}(\mathrm{HCl})$ measured in our work and that of Keene et al. (2006). $\mathrm{CH}_{3} \mathrm{Cl}$ was not measured by OP-FTIR in this study due to its weak absorbance and overlap with strong $\mathrm{H}_{2} \mathrm{O}$ and $\mathrm{CO}_{2}$ lines, but $\mathrm{CH}_{3} \mathrm{Cl}$ data for these fires from the GC-MS may be available for comparison to $\mathrm{HCl}$ in future papers. Finally, we note that recent work shows that the interaction of $\mathrm{HCl}$ and $\mathrm{NO}_{\mathrm{x}}$ (a major biomass burning emission) can lead to reactive products that could impact $\mathrm{O}_{3}$ formation (Raff et al., 2009; Thornton et al., 2010).

Chloride is supplied to plants from several sources, including the soil, rain, and air pollution (Marschner, 1986). Since several of the fuels burned in this study are located in coastal regions, deposition of marine aerosol is also a likely source impacting the emissions of $\mathrm{HCl}$ when the vegetation burns (McKenzie et al., 1996). However, the Vandenberg AFB fuels California sage and manzanita, co-located at approximately $4.3 \mathrm{~km}$ from the coast, and coastal sage scrub and maritime chaparral, co-located at roughly $9 \mathrm{~km}$ from the coast, show large differences in $\mathrm{EF}(\mathrm{HCl})$ for the colocated species. The same effect is observed in the two Fort Hunter-Liggett fuels (ceanothus, chamise/scruboak) both colocated approximately $11.6 \mathrm{~km}$ from the coast. These results imply an additional dependence on the specific characteristics of the individual plant species comprising the fuel types and their burning behavior or potentially other localized $\mathrm{Cl}$ sources. With two of the sites in this study, Fort Huachuca and Fort Benning, being located far inland, soil storage and precipitation are the likely $\mathrm{Cl}$ sources at these locations.

\subsection{Emissions of $\mathrm{SO}_{2}$}

Sulfur dioxide was also emitted with significant emission factors in these fires, exclusively as a flaming combustion product. The emission factors for $\mathrm{SO}_{2}$ observed in this study are comparable to those compiled by Andreae and Merlet (2001), or slightly higher. As with $\mathrm{HCl}, \mathrm{EF}\left(\mathrm{SO}_{2}\right)$ is highly variable and dependent on the fuel type and burning behavior. Sulfur, designated a plant macronutrient, is primarily taken up by higher plants from the soil in the form of sulfate. Atmospheric gas-phase $\mathrm{SO}_{2}$ (Marschner, 1986) and carbonyl sulfide (COS) (Stimler et al., 2010) are taken up through leaf stomates and used by aerial portions of the plant. Leaves have the highest sulfur content in plants (Lorenzini and Panicucci, 1994). While $\mathrm{SO}_{2}$ has been established previously as a product of flaming combustion (Andreae and Merlet, 2001; Yokelson et al., 1996), $\mathrm{EF}\left(\mathrm{SO}_{2}\right)$ decreases with increasing MCE with a linear fit of $\mathrm{EF}\left(\mathrm{SO}_{2}\right)=-12.40( \pm 1.43) \times \mathrm{MCE}+12.55( \pm 1.35)$ with an $R^{2}$ value of 0.55 . The inverse dependence of $\mathrm{SO}_{2}$ on MCE in our study was also observed by Sinha et al. (2003) and is likely due to different sulfur content in the fuels, in a manner similar to that of the fuel nitrogen dependence described previously. For example, in our study, the fuel type sampled at Fort Benning (pine litter) burned with the lowest MCE yet the $\mathrm{SO}_{2}$ emission factor was highest. Figure 10 shows the instantaneous excess $\mathrm{SO}_{2}$ mixing ratio as a function of excess $\mathrm{CO}_{2}$ and $\mathrm{CO}$ over time for a single fire. From this figure it is obvious that $\mathrm{SO}_{2}$ is directly correlated to $\mathrm{CO}_{2}$ and not correlated to $\mathrm{CO}$ indicating that $\mathrm{SO}_{2}$ is a flaming combustion product (Lobert et al., 1991). A possible explanation for the loop trajectory of $\mathrm{SO}_{2}$ as a function of $\mathrm{CO}_{2}$ observed in Fig. 10 is that at the beginning of flaming combustion $\left(\mathrm{CO}_{2}\right.$ increases with time), the vegetation components containing the higher sulfur content burn first (leaves, for example) and completely, then as flaming combustion diminishes $\left(\mathrm{CO}_{2} \mathrm{de}-\right.$ creases with time) the lower sulfur components of vegetation burn.

\subsection{Comparison with field measurements of emission factors for SW and SE US biomass burning}

There have been emission factors previously measured in the field for $\mathrm{CO}, \mathrm{CO}_{2}, \mathrm{NO}_{\mathrm{x}}, \mathrm{NH}_{3}$, a few hydrocarbons, $\mathrm{PM}_{2.5}$, and $\mathrm{PM}_{10}$, for chaparral, but the technology at the time did not permit measurement of EFs for OVOC, and many of the gaseous compounds that can be identified by OP-FTIR. We determined the average EFs for all species belonging to chaparral (all California species sampled here) as well as the averages for all fuels collected from Fort Huachuca (Table 2). Also shown in Table 2 are the airborne EF measurements of chaparral burns from Radke et al. (1991). The average chaparral MCE for these two data sets is very similar, but the emission factors are in general lower for our laboratory data. Some of the chaparral fires sampled by Radke et al. (1991) 

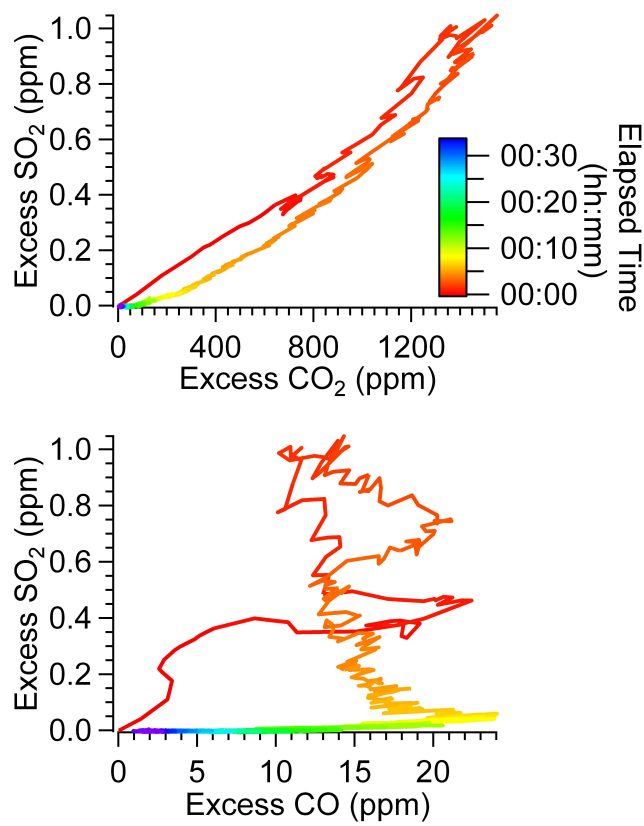

Fig. 10. Evolution of excess $\mathrm{SO}_{2}$ as a function of excess $\mathrm{CO}_{2}$ (top graph) and as a function of $\mathrm{CO}$ (bottom graph) for a typical fire.

were located at the San Dimas Experimental Forest which has been shown to be significantly impacted by nitrogen deposition of local air pollution (Riggan et al., 1985; Fenn et al., 1996). The impact of urban pollution on the California sites in our study is likely minimal. These differences will be further assessed elsewhere with the benefit of data from our airborne field measurements.

Our laboratory EFs from Camp Lejeune fuels show significant differences with the airborne field measurements of EF from Camp Lejeune reported by Yokelson et al. (1999), which are also shown in Table 3. The fuels in the latter study were impacted by hurricanes. Our recent field study provided many more airborne EF from Camp Lejeune and similar ecosystems nearby, which were not impacted by hurricanes and will be considered along with the lab work in a separate publication.

It is also possible to compare our results with the very limited amount of previous work on the impact of fuel treatments on emissions. Four of the samples at Camp Lejeune in North Carolina represent fuel treatments typically utilized at this base (understory hardwood (baseline, no treatment), chipped understory hardwood, one- and two-year rough regrowth). Figure 11 shows the emission factors for selected gas-phase species for each of these Camp Lejeune fuel types arranged in descending order of MCE. From this figure, one general trend is that the NMOC EFs increase as MCE decreases. The chipped understory hardwood samples burned with the highest MCE and had the lowest EFs for all NMOC. Hardy et al. (1996) also found that fuel mastication in the chaparral ecosystem resulted in fires burning with higher

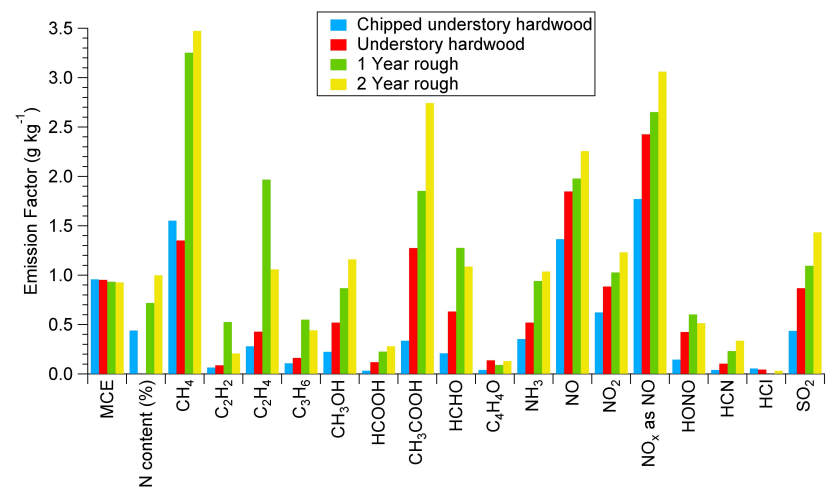

Fig. 11. Emission factors for fuels representing various land management strategies at Camp Lejeune. MCE (unitless) and fuel nitrogen content $(\%)$ are shown on the same scale. The nitrogen content of the understory hardwood sample was not determined.

MCE and lower EF(NMOC). However, the EF(NMOC) are consistently much larger for the 1 and 2 year regrowth than for the untreated fuels.

\section{Conclusions}

We have investigated the gas-phase emissions from burning samples of the fuels typically managed with prescribed fire on military bases in the southeastern and southwestern US. We report emission factors for the many gas-phase species measured by OP-FTIR. The emission factors show large fuel composition and regional dependences, particularly when comparing the southwestern versus the southeastern fuel types. Of particular interest was the observation of elevated amounts of HONO in the initial emissions of all fires we sampled. Emission factors for $\mathrm{HONO}$ ranged from 0.15 to $0.60 \mathrm{~g} \mathrm{~kg}^{-1}$ and $\Delta \mathrm{HONO} / \Delta \mathrm{NO}_{\mathrm{x}}$ ranged from 0.025 to 0.20 depending on fuel type burned. The HONO emissions observed here could represent a significant source of $\mathrm{OH}$ in the plume, contributing to rapid formation of aerosol and $\mathrm{O}_{3}$ as the plume ages.

Significant emissions of NMOC were measured by OPFTIR and the majority were the oxygenated volatile organic compounds, $\mathrm{HCHO}, \mathrm{CH}_{3} \mathrm{OH}, \mathrm{CH}_{3} \mathrm{COOH}$ with molar OVOC/NMOC ratios of $56 \%$ and $69 \%$ for the southwestern and southeastern fuels, respectively. The emission factors of these compounds were similar to previously published results. The non-methane hydrocarbon species measured here are important due to their reactions with oxidants in the plume. The significance of the large amounts of OVOC is that in addition to oxidation reactions, for many of these compounds photolysis is also important. Photolysis of these OVOC can make them an important source of additional oxidants in the plume (Singh et al., 1995). 
We measured emission factors for several nitrogencontaining species, $\mathrm{NO}, \mathrm{NO}_{2}, \mathrm{NH}_{3}, \mathrm{HCN}$, and $\mathrm{HONO}$. Emission factors for these compounds were dependent on MCE, and fuel nitrogen content. These compounds accounted for approximately 16 to $43 \%$ of the fuel nitrogen, with the fraction unaccounted for dependent on MCE. Most of the nitrogen not accounted for likely is emitted as molecular $\mathrm{N}_{2}$, a dominant nitrogen product of flaming combustion (Kuhlbusch et al., 1991) or remains in the ash.

Elevated amounts of $\mathrm{HCl}$ were observed for many of the fuel types sampled here. The $\mathrm{HCl}$ emission factors were highly variable and in general higher in the coastal regions (Fort Hunter-Liggett, Vandenberg AFB, Camp Lejeune) but we also observed significant emissions for fuels obtained at sites much farther inland (Fort Huachuca, Fort Benning).

$\mathrm{SO}_{2}$ was observed as a flaming compound from these fires. However, our $\mathrm{SO}_{2}$ emission factors decreased with increasing MCE suggesting this emission factor was most strongly influenced by fuel sulfur content. This is analogous to the dependence of the nitrogen-containing emissions on fuel nitrogen content.

Acknowledgements. This work was supported by the Strategic Environmental Research and Development Program (SERDP) projects SI-1648 and SI-1649 and administered through Forest Service Research Joint Venture Agreement 08JV11272166039, and we thank the sponsors for their support. P. Veres, J. M. Roberts, C. Warneke, J. de Gouw were supported in part by NSF Grant \# ATM 1542457 and the CIRES Innovative Research Program. We appreciate the efforts of Joey Chong, Bonni Corcoran, Amy Olson, Violet Holly, Signe Leirfallom, and Emily Lincoln to harvest the fuels and assemble the fuel beds for this study. The cooperation of Dan Ardoin and personnel at Vandenberg AFB, Jeff Minetti and personnel at Ft. Hunter-Liggett, Andrew Leiendecker and personnel at Ft. Huachuca, and Danny Becker, Susan Cohen, Wayne Gray, and Gary Curcio at Camp Lejeune is greatly appreciated.

Edited by: M. Petters

\section{References}

Alvarado, M. J. and Prinn, R. G.: Formation of ozone and growth of aerosols in young smoke plumes from biomass burning: 1. Lagrangian parcel studies, J. Geophys. Res., 114, D09306, doi:10.1029/2008jd011144, 2009.

Alvarado, M. J., Wang, C., and Prinn, R. G.: Formation of ozone and growth of aerosols in young smoke plumes from biomass burning: 2. Three-dimensional Eulerian studies, J. Geophys. Res., 114, D09307, doi:10.1029/2008jd011186, 2009.

Andreae, M. O. and Merlet, P.: Emission of trace gases and aerosols from biomass burning, Global Biogeochem. Cy., 15, 955-966, 2001.

Biswell, H.: Prescribed Burning in California Wildlands Vegetation Management University of California Press, Berkeley, CA, 255 pp., 1999.

Bröske, R., Kleffmann, J., and Wiesen, P.: Heterogeneous conversion of NO2 on secondary organic aerosol surfaces: A possi- ble source of nitrous acid (HONO) in the atmosphere?, Atmos. Chem. Phys., 3, 469-474, doi:10.5194/acp-3-469-2003, 2003.

Byun, D. and Schere, K. L.: Review of the Governing Equations, Computational Algorithms, and Other Components of the Models-3 Community Multiscale Air Quality (CMAQ) Modeling System, Appl. Mech. Rev., 59, 51-77, 2006.

Christian, T. J., Kleiss, B., Yokelson, R. J., Holzinger, R., Crutzen, P. J., Hao, W. M., Saharjo, B. H., and Ward, D. E.: Comprehensive laboratory measurements of biomass-burning emissions: 1 . Emissions from Indonesian, African, and other fuels, J. Geophys. Res., 108, 4719, doi:10.1029/2003jd003704, 2003.

Christian, T. J., Kleiss, B., Yokelson, R. J., Holzinger, R., Crutzen, P. J., Hao, W. M., Shirai, T., and Blake, D. R.: Comprehensive laboratory measurements of biomass-burning emissions: 2. First intercomparison of open-path FTIR, PTRMS, and GC-MS/FID/ECD, J. Geophys. Res., 109, D02311, doi:10.1029/2003jd003874, 2004.

Crounse, J. D., DeCarlo, P. F., Blake, D. R., Emmons, L. K., Campos, T. L., Apel, E. C., Clarke, A. D., Weinheimer, A. J., McCabe, D. C., Yokelson, R. J., Jimenez, J. L., and Wennberg, P. O.: Biomass burning and urban air pollution over the Central Mexican Plateau, Atmos. Chem. Phys., 9, 4929-4944, doi:10.5194/acp-9-4929-2009, 2009.

Crutzen, P. J. and Andreae, M. O.: Biomass burning in the tropics: Impact on atmospheric chemistry and biogeochemical cycles, Science, 250, 1669-1677, 1990.

de Gouw, J. and Warneke, C.: Measurements of volatile organic compounds in the earth's atmosphere using proton-transferreaction mass spectrometry, Mass Spectrom. Rev., 26, 223-257, doi:10.1002/mas.20119, 2007.

de Gouw, J. A., Warneke, C., Parrish, D. D., Holloway, J. S., Trainer, M., and Fehsenfeld, F. C.: Emission sources and ocean uptake of acetonitrile $\left(\mathrm{CH}_{3} \mathrm{CN}\right)$ in the atmosphere, J. Geophys. Res., 108, 4329, doi:10.1029/2002jd002897, 2003.

Fenn, M. E., Poth, M. A., and Johnson, D. W.: Evidence for nitrogen saturation in the San Bernardino Mountains in southern California, For. Ecol. Manage., 82, 211-230, 1996.

Finlayson-Pitts, B. J. and Pitts, J. N. J.: Chemistry of the Upper and Lower Atmosphere: Theory, Experiments, and Applications, Academic Press, San Diego, CA, 969 pp., 2000.

Gherman, T., Venables, D. S., Vaughan, S., Orphal, J., and Ruth, A. A.: Incoherent broadband cavity-enhanced absorption spectroscopy in the near-ultraviolet: Application to $\mathrm{HONO}$ and $\mathrm{NO}_{2}$, Environ. Sci. Technol., 42, 890-895, doi:10.1021/es0716913, 2007.

Goldan, P. D., Kuster, W. C., Williams, E., Murphy, P. C., Fehsenfeld, F. C., and Meagher, J.: Nonmethane hydrocarbon and oxy hydrocarbon measurements during the 2002 New England Air Quality Study, J. Geophys. Res., 109, D21309, doi:10.1029/2003jd004455, 2004.

Goode, J. G., Yokelson, R. J., Susott, R. A., and Ward, D. E.: Trace gas emissions from laboratory biomass fires measured by open-path Fourier transform infrared spectroscopy: Fires in grass and surface fuels, J. Geophys. Res., 104, 21237-21245, doi:10.1029/1999jd900360, 1999.

Goode, J. G., Yokelson, R. J., Ward, D. E., Susott, R. A., Babbitt, R. E., Davies, M. A., and Hao, W. M.: Measurements of excess $\mathrm{O}_{3}, \mathrm{CO}_{2}, \mathrm{CO}, \mathrm{CH}_{4}, \mathrm{C}_{2} \mathrm{H}_{4}, \mathrm{C}_{2} \mathrm{H}_{2}, \mathrm{HCN}, \mathrm{NO}, \mathrm{NH}_{3}$, $\mathrm{HCOOH}, \mathrm{CH}_{3} \mathrm{COOH}, \mathrm{HCHO}$, and $\mathrm{CH}_{3} \mathrm{OH}$ in 1997 Alaskan 
biomass burning plumes by airborne Fourier transform infrared spectroscopy (AFTIR), J. Geophys. Res., 105, 22147-22166, doi:10.1029/2000jd900287, 2000.

Griffith, D. W. T.: Synthetic calibration and quantitative analysis of gas phase infrared spectra, Appl. Spectrosc., 50, 59-70, 1996.

Griffith, D. W. T., Mankin, W. G., Coffey, M. T., Ward, D. E., and Riebau, A.: FTIR remote sensing of biomass burning emissions of $\mathrm{CO}_{2}, \mathrm{CO}, \mathrm{CH}_{4}, \mathrm{CH}_{2} \mathrm{O}, \mathrm{NO}, \mathrm{NO}_{2}, \mathrm{NH}_{3}$, and $\mathrm{N}_{2} \mathrm{O}$, in: Global Biomass Burning: Atmospheric, Climatic, and Biospheric Implications, edited by: Levine, J. S., MIT Press, Cambridge, 230239, 1991.

Hao, W. M., Scharffe, D., Lobert, J. M., and Crutzen, P. J.: Emissions of $\mathrm{N}_{2} \mathrm{O}$ from the burning of biomass in an experimental system, Geophys. Res. Lett., 18, 999-1002, doi:10.1029/90gl02583, 1991.

Hao, W. M., Ward, D. E., Olbu, G., and Baker, S. P.: Emissions of $\mathrm{CO}_{2}, \mathrm{CO}$, and hydrocarbons from fires in diverse African savanna ecosystems, J. Geophys. Res., 101, 2357723584, doi:10.1029/95jd02198, 1996.

Hardy, C. C., Conard, S. G., Regelbrugge, J. C., and Teesdale, D. R.: Smoke emissions from prescribed burning of southern California chaparral, USDA Forest Service, Portland, OR, Research Paper PNW-RP-486, 37 pp., 1996.

Hosseini, S., Li, Q., Cocker, D., Weise, D., Miller, A., Shrivastava, M., Miller, J. W., Mahalingam, S., Princevac, M., and Jung, H.: Particle size distributions from laboratory-scale biomass fires using fast response instruments, Atmos. Chem. Phys., 10, 80658076, doi:10.5194/acp-10-8065-2010, 2010.

Johnson, T. J., Masiello, T., and Sharpe, S. W.: The quantitative infrared and NIR spectrum of $\mathrm{CH}_{2} \mathrm{I}_{2}$ vapor: vibrational assignments and potential for atmospheric monitoring, Atmos. Chem. Phys., 6, 2581-2591, doi:10.5194/acp-6-2581-2006, 2006.

Johnson, T. J., Profeta, L. T. M., Sams, R. L., Griffith, D. W. T., and Yokelson, R. L.: An infrared spectral database for detection of gases emitted by biomass burning, Vib. Spectrosc., 53, 97-102, doi:10.1016/j.vibspec.2010.02.010, 2010.

Kalberer, M., Ammann, M., Arens, F., Gäggeler, H. W., and Baltensperger, U.: Heterogeneous formation of nitrous acid (HONO) on soot aerosol particles, J. Geophys. Res., 104, 1382513832, doi:10.1029/1999jd900141, 1999.

Keeley, J. E. and Davis, F. W.: Chaparral, in: Terrestrial Vegetation of California, 3rd ed., edited by: Barbour, M., Keeler-Wolf, T., and Schoenherr, A. A., University of California Press, Los Angeles, 339-366, 2007.

Keene, W. C., Lobert, J. M., Crutzen, P. J., Maben, J. R., Scharffe, D. H., Landmann, T., Hély, C., and Brain, C.: Emissions of major gaseous and particulate species during experimental burns of southern African biomass, J. Geophys. Res., 111, D04301, doi:10.1029/2005jd006319, 2006.

Kleffmann, J.: Daytime sources of nitrous acid (HONO) in the atmospheric boundary layer, ChemPhysChem, 8, 1137-1144, doi:10.1002/cphc.200700016, 2007.

Kleffmann, J., Becker, K. H., Lackhoff, M., and Wiesen, P.: Heterogeneous conversion of $\mathrm{NO}_{2}$ on carbonaceous surfaces, Phys. Chem. Chem. Phys., 1, 5443-5450, 1999.

Kuhlbusch, T. A., Lobert, J. M., Crutzen, P. J., and Warneck, P.: Molecular nitrogen emissions from denitrification during biomass burning, Nature, 351, 135-137, doi:10.1038/351135a0, 1991.
Kuhlbusch, T. A. J., Andreae, M. O., Cachier, H., Goldammer, J. G., Lacaux, J. P., Shea, R., and Crutzen, P. J.: Black carbon formation by savanna fires: Measurements and implications for the global carbon cycle, J. Geophys. Res., 101, 23651-23665, doi:10.1029/95jd02199, 1996.

Li, Q., Jacob, D. J., Bey, I., Yantosca, R. M., Zhao, Y., Kondo, Y., and Notholt, J.: Atmospheric hydrogen cyanide (HCN): biomass burning source, ocean sink?, Geophys. Res. Lett., 27, 357-360, 2000.

Lobert, J. M., Scharffe, D. H., Hao, W. M., Kuhlbusch, T. A., Seuwen, R., Warneck, P., and Crutzen, P. J.: Experimental evaluation of biomass burning emissions: Nitrogen and carbon containing compounds, in: Global Biomass Burning: Atmospheric, Climatic, and Biospheric Implications, edited by: Levine, J. S., MIT Press, Cambridge, 289-304, 1991.

Lobert, J. M., Keene, W. C., Logan, J. A., and Yevich, R.: Global chlorine emissions from biomass burning: Reactive Chlorine Emissions Inventory, J. Geophys. Res., 104, 8373-8389, doi:10.1029/1998jd100077, 1999.

Lorenzini, G. and Panicucci, A.: Is sulfur accumulation in sulfur dioxide-exposed plants related to biomass reduction?, Bull. Environ. Contam. Toxicol., 52, 802-809, 1994.

Marschner, H.: Mineral Nutrition of Higher Plants, Academic Press, San Diego, CA, 674 pp., 1986.

McKenzie, L. M., Ward, D. E., and Hao, W. M.: Chlorine and Bromine in the biomass of tropical and temperate ecosystems, in: Biomass Burning and Global Change, edited by: Levine, J. S., MIT Press, Cambridge, 2412-2248, 1996.

McMeeking, G. R., Kreidenweis, S. M., Baker, S., Carrico, C. M., Chow, J. C., Collett, J. L., Jr., Hao, W. M., Holden, A. S., Kirchstetter, T. W., Malm, W. C., Moosmüller, H., Sullivan, A. P., and Wold, C. E.: Emissions of trace gases and aerosols during the open combustion of biomass in the laboratory, J. Geophys. Res., 114, D19210, doi:10.1029/2009jd011836, 2009.

Perrin, A. and Vander Auwera, J.: An improved database for the $9 \mu \mathrm{m}$ region of the formic acid spectrum, J. Quant. Spectrosc. Ra., 108, 363-370, doi:10.1016/j.jqsrt.2007.05.002, 2007.

Radke, L. F., Hegg, D. A., Hobbs, P. V., Nance, J. D., Lyons, J. H., Laursen, K. K., Weiss, R. E., Riggan, P. J., and Ward, D. E.: Particulate and trace gas emissions from large biomass fires in North America, in: Global Biomass Burning: Atmospheric, Climatic, and Biospheric Implications, edited by: Levine, J. S., MIT Press, Cambridge, MA, 209-224, 1991.

Raff, J. D., Njegic, B., Chang, W. L., Gordon, M. S., Dabdub, D., Gerber, R. B., and Finlayson-Pitts, B. J.: Chlorine activation indoors and outdoors via surface-mediated reactions of nitrogen oxides with hydrogen chloride, P. Natl. Acad. Sci. USA, 106, 13647-13654, doi:10.1073/pnas.0904195106, 2009.

Riggan, P. J., Lockwood, R. N., and Lopez, E. N.: Deposition and processing of airborne nitrogen pollutants in Mediterranean-type ecosystems of southern California, Environ. Sci. Technol., 19, 781-789, doi:10.1021/es00139a003, 1985.

Roberts, J. M., Veres, P., Warneke, C., Neuman, J. A., Washenfelder, R. A., Brown, S. S., Baasandorj, M., Burkholder, J. B., Burling, I. R., Johnson, T. J., Yokelson, R. J., and de Gouw, J.: Measurement of HONO, HNCO, and other inorganic acids by negative-ion proton-transfer chemical-ionization mass spectrometry (NI-PT-CIMS): application to biomass burning emissions, Atmos. Meas. Tech., 3, 981-990, doi:10.5194/amt-3-981-2010, 
2010.

Rothman, L. S., Gordon, I. E., Barbe, A., Benner, D. C., Bernath, P. F., Birk, M., Boudon, V., Brown, L. R., Campargue, A., Champion, J. P., Chance, K., Coudert, L. H., Dana, V., Devi, V. M., Fally, S., Flaud, J. M., Gamache, R. R., Goldman, A., Jacquemart, D., Kleiner, I., Lacome, N., Lafferty, W. J., Mandin, J. Y., Massie, S. T., Mikhailenko, S. N., Miller, C. E., Moazzen-Ahmadi, N., Naumenko, O. V., Nikitin, A. V., Orphal, J., Perevalov, V. I., Perrin, A., Predoi-Cross, A., Rinsland, C. P., Rotger, M., Simecková, M., Smith, M. A. H., Sung, K., Tashkun, S. A., Tennyson, J., Toth, R. A., Vandaele, A. C., and Vander Auwera, J.: The HITRAN 2008 molecular spectroscopic database, J. Quant. Spectrosc. Ra., 110, 533-572, 2009.

Sharpe, S. W., Johnson, T. J., Sams, R. L., Chu, P. M., Rhoderick, G. C., and Johnson, P. A.: Gas-phase databases for quantitative infrared spectroscopy, Appl. Spectrosc., 58, 1452-1461, 2004.

Singh, H. B., Kanakidou, M., Crutzen, P. J., and Jacob, D. J.: High concentrations and photochemical fate of oxygenated hydrocarbons in the global troposphere, Nature, 378, 50-54, 1995.

Sinha, P., Hobbs, P. V., Yokelson, R. J., Bertschi, I. T., Blake, D. R., Simpson, I. J., Gao, S., Kirchstetter, T. W., and Novakov, T.: Emissions of trace gases and particles from savanna fires in southern Africa, J. Geophys. Res., 108, 8487, doi:10.1029/2002jd002325, 2003.

Stadler, D. and Rossi, M. J.: The reactivity of $\mathrm{NO}_{2}$ and $\mathrm{HONO}$ on flame soot at ambient temperature: The influence of combustion conditions, Phys. Chem. Chem. Phys., 2, 5420-5429, 2000.

Stemmler, K., Ndour, M., Elshorbany, Y., Kleffmann, J., D’Anna, B., George, C., Bohn, B., and Ammann, M.: Light induced conversion of nitrogen dioxide into nitrous acid on submicron humic acid aerosol, Atmos. Chem. Phys., 7, 4237-4248, doi:10.5194/acp-7-4237-2007, 2007.

Stimler, K., Montzka, S. A., Berry, J. A., Rudich, Y., and Yakir, D.: Relationships between carbonyl sulfide (COS) and $\mathrm{CO}_{2}$ during leaf gas exchange, New Phytol., 186, 869-878, 2010.

Stutz, J., Oh, H.-J., Whitlow, S. I., Anderson, C., Dibb, J. E., Flynn, J. H., Rappenglück, B., and Lefer, B.: Simultaneous DOAS and mist-chamber IC measurements of HONO in Houston, TX, Atmos. Environ., 44, 4090-4098, 2010.

Thornton, J. A., Kercher, J. P., Riedel, T. P., Wagner, N. L., Cozic, J., Holloway, J. S., Dubé, W. P., Wolfe, G. M., Quinn, P. K., Middlebrook, A. M., Alexander, B., and Brown, S. S.: A large atomic chlorine source inferred from mid-continental reactive nitrogen chemistry, Nature, 464, 271-274, 2010.

Trentmann, J., Yokelson, R. J., Hobbs, P. V., Winterrath, T., Christian, T. J., Andreae, M. O., and Mason, S. A.: An analysis of the chemical processes in the smoke plume from a savanna fire, J. Geophys. Res., 110, D12301, doi:10.1029/2004jd005628, 2005.

Urbanski, S. P., Hao, W. M., and Baker, S.: Chemical composition of wildland fire emissions, in: Wildland Fires and Air Pollution, edited by: Bytnerowicz, A., Arbaugh, M., Riebau, A., and Andersen, C., Developments in Environmental Science, Elsevier, Amsterdam, 8, 79-107, 2009.

US National Interagency Fire Center: http://www.nifc.gov/fire info/fire_stats.htm, access: 2 June 2010.

Veres, P., Roberts, J. M., Warneke, C., Welsh-Bon, D., Zahniser, M., Herndon, S., Fall, R., and de Gouw, J.: Development of negativeion proton-transfer chemical-ionization mass spectrometry (NIPT-CIMS) for the measurement of gas-phase organic acids in the atmosphere, Int. J. Mass Spectrom., 274, 48-55, 2008.

Veres, P., Roberts, J. M., Burling, I. R., Warneke, C., de Gouw, J., and Yokelson, R. J.: Measurements of gas-phase inorganic and organic acids from biomass fires by negative-ion proton-transfer chemical-ionization mass spectrometry (NI-PT-CIMS), J. Geophys. Res., doi:10.1029/2010JD014033, in press, 2010.

Wade, D. D. and Lunsford, J. D.: A guide for prescribed fire in southern forests, Atlanta, GA, 56 pp., 1989.

Warneke, C., Kato, S., de Gouw, J. A., Goldan, P. D., Kuster, W. C., Shao, M., Lovejoy, E. R., Fall, R., and Fehsenfeld, F. C.: Online Volatile Organic Compound Measurements Using a Newly Developed Proton-Transfer Ion-Trap Mass Spectrometry Instrument during New England Air Quality StudyIntercontinental Transport and Chemical Transformation 2004: Performance, Intercomparison, and Compound Identification, Environ. Sci. Technol., 39, 5390-5397, doi:10.1021/es050602o, 2005.

Warneke, C., Roberts, J. M., Veres, P., Gilman, J., Kuster, W. C., Burling, I. R., Yokelson, R. J., and de Gouw, J. A.: VOC identification and inter-comparison from laboratory biomass burning using PTR-MS and PIT-MS, Atmos. Chem. Phys. Discuss., 2010.

Yokelson, R. J., Griffith, D. W. T., and Ward, D. E.: Openpath Fourier transform infrared studies of large-scale laboratory biomass fires, J. Geophys. Res., 101, 21067-21080, doi:10.1029/96jd01800, 1996.

Yokelson, R. J., Goode, J. G., Ward, D. E., Susott, R. A., Babbitt, R. E., Wade, D. D., Bertschi, I., Griffith, D. W. T., and Hao, W. M.: Emissions of formaldehyde, acetic acid, methanol, and other trace gases from biomass fires in North Carolina measured by airborne Fourier transform infrared spectroscopy, J. Geophys. Res., 104, 30109-30125, doi:10.1029/1999jd900817, 1999.

Yokelson, R. J., Bertschi, I. T., Christian, T. J., Hobbs, P. V., Ward, D. E., and Hao, W. M.: Trace gas measurements in nascent, aged, and cloud-processed smoke from African savanna fires by airborne Fourier transform infrared spectroscopy (AFTIR), J. Geophys. Res., 108, 8478, doi:10.1029/2002jd002322, 2003.

Yokelson, R. J., Karl, T., Artaxo, P., Blake, D. R., Christian, T. J., Griffith, D. W. T., Guenther, A., and Hao, W. M.: The Tropical Forest and Fire Emissions Experiment: overview and airborne fire emission factor measurements, Atmos. Chem. Phys., 7, 5175-5196, doi:10.5194/acp-7-5175-2007, 2007a.

Yokelson, R. J., Urbanski, S. P., Atlas, E. L., Toohey, D. W., Alvarado, E. C., Crounse, J. D., Wennberg, P. O., Fisher, M. E., Wold, C. E., Campos, T. L., Adachi, K., Buseck, P. R., and Hao, W. M.: Emissions from forest fires near Mexico City, Atmos. Chem. Phys., 7, 5569-5584, doi:10.5194/acp-7-5569-2007, 2007b.

Yokelson, R. J., Christian, T. J., Karl, T. G., and Guenther, A.: The tropical forest and fire emissions experiment: laboratory fire measurements and synthesis of campaign data, Atmos. Chem. Phys., 8, 3509-3527, doi:10.5194/acp-8-3509-2008, 2008.

Yokelson, R. J., Crounse, J. D., DeCarlo, P. F., Karl, T., Urbanski, S., Atlas, E., Campos, T., Shinozuka, Y., Kapustin, V., Clarke, A. D., Weinheimer, A., Knapp, D. J., Montzka, D. D., Holloway, J., Weibring, P., Flocke, F., Zheng, W., Toohey, D., Wennberg, P. O., Wiedinmyer, C., Mauldin, L., Fried, A., Richter, D., Walega, J., Jimenez, J. L., Adachi, K., Buseck, P. R., Hall, S. R., and Shetter, R.: Emissions from biomass burning in the Yucatan, Atmos. Chem. Phys., 9, 5785-5812, doi:10.5194/acp-9-5785-2009, 2009. 